IZA DP No. 7969

Tariffs, Social Status, and Gender in India

S Anukriti

Todd J. Kumler

February 2014 


\title{
Tariffs, Social Status, and Gender in India
}

\author{
S Anukriti \\ Boston College \\ and IZA
}

Todd J. Kumler

Columbia University

\section{Discussion Paper No. 7969 \\ February 2014}

\author{
IZA \\ P.O. Box 7240 \\ 53072 Bonn \\ Germany \\ Phone: +49-228-3894-0 \\ Fax: +49-228-3894-180 \\ E-mail: iza@iza.org
}

Any opinions expressed here are those of the author(s) and not those of IZA. Research published in this series may include views on policy, but the institute itself takes no institutional policy positions. The IZA research network is committed to the IZA Guiding Principles of Research Integrity.

The Institute for the Study of Labor (IZA) in Bonn is a local and virtual international research center and a place of communication between science, politics and business. IZA is an independent nonprofit organization supported by Deutsche Post Foundation. The center is associated with the University of Bonn and offers a stimulating research environment through its international network, workshops and conferences, data service, project support, research visits and doctoral program. IZA engages in (i) original and internationally competitive research in all fields of labor economics, (ii) development of policy concepts, and (iii) dissemination of research results and concepts to the interested public.

IZA Discussion Papers often represent preliminary work and are circulated to encourage discussion. Citation of such a paper should account for its provisional character. A revised version may be available directly from the author. 
IZA Discussion Paper No. 7969

February 2014

\section{ABSTRACT}

\section{Tariffs, Social Status, and Gender in India*}

This paper shows that trade policy can have significant intergenerational distributional effects across gender and social strata. We compare women and births in rural Indian districts more or less exposed to tariff cuts. For low socioeconomic status women, tariff cuts increase the likelihood of a female birth and these daughters are less likely to die during infancy and childhood. On the contrary, high-status women are less likely to give birth to girls and their daughters have higher mortality rates when more exposed to tariff declines. Consistent with the fertility-sex ratio trade-off in high son preference societies, fertility increases for low-status women and decreases for high-status women. An exploration of the mechanisms suggests that the labor market returns for low-status women (relative to men) and high-status men (relative to women) have increased in response to trade liberalization. Thus, altered expectations about future returns from daughters relative to sons seem to have caused families to change the sex-composition of and health investments in their children.

JEL Classification: $\quad \mathrm{F} 13, \mathrm{I15}, \mathrm{J} 12, \mathrm{J13}, \mathrm{J} 16, \mathrm{~J} 82, \mathrm{O} 15, \mathrm{O} 18, \mathrm{O} 19, \mathrm{O} 24$

Keywords: $\quad$ trade liberalization, India, gender, sex ratio, child mortality, fertility

Corresponding author:

S Anukriti

Department of Economics

Boston College

140 Commonwealth Avenue

Chestnut Hill, MA 02467

USA

E-mail: anukriti@bc.edu

\footnotetext{
*We are grateful to Petia Topalova and Ram Fishman for sharing their data. We also thank David Blakeslee, Ritam Chaurey, Pierre-André Chiappori, Lena Edlund, Eric Edmonds, Naihobe Gonzalez, Amit Khandelwal, Brian Kovak, Dilip Mookherjee, Arvind Panagariya, Cristian Pop-Eleches, Debraj Ray, Bernard Salanié, Rohini Somanathan, Hyelim Son, and Eric Verhoogen for their valuable comments. This paper benefitted from presentations at the Population Association of America Annual Meetings, the NEUDC Conference, the Delhi School of Economics, and Columbia University. All errors are our own.
} 


\section{Introduction}

Macroeconomic policies have microeconomic consequences as they alter prices, incomes, and the choice sets of individuals and firms. This paper focuses on one of the most important structural changes in recent history - the removal of international trade barriers. Specifically, in the context of India, we examine the implications of tariff cuts for fertility, sex-selection, and child mortality, and highlight the distributional effects of trade policy across gender and socioeconomic strata.

The 1991 trade liberalization of the Indian economy was externally imposed by the International Monetary Fund (IMF) in response to a severe balance of payments crisis, which we argue was an exogenous shock to industry-level tariffs in India. Moreover, the resulting changes in tariff- and non-tariff barriers (NTBs) were quite large in magnitude. In the manufacturing sector, the average tariff declined from 117 percent to 39 percent and the share of imports covered by NTBs fell from 82 percent to 17 percent between 1990-1991 and 1999-2000 (Gupta and Kumar (2008)). We exploit heterogeneity in the pre-reform industrial composition of Indian districts, combined with differences in tariff cuts by industry, to identify districts that were more or less exposed to trade liberalization. ${ }^{1}$ We then estimate the effect of this differential exposure on parents' fertility decisions and children's health.

Using retrospective birth histories constructed from large-scale household surveys and an instrumentalvariables strategy, first we show that the sex ratio at birth decreased and fertility as well as child mortality increased in districts more exposed to tariff cuts. However, these effects vary significantly across social strata. We find that tariff cuts improve the likelihood of birth and survival for girls in socially disadvantaged families. Births to lower-caste, uneducated, and less wealthy women are more likely to be female in districts that are relatively more exposed to tariff declines. Moreover, these daughters are significantly less likely to die within one, six, and twelve months of birth. However, mortality for girls born to upper-caste, more educated, and wealthier mothers increases significantly. These "high-status" women are also more likely to give birth to boys, but the sex ratio effects are not as strong as the mortality results. Fertility rises for

\footnotetext{
${ }^{1}$ Among several other papers, this identification strategy has been used by Hasan et al. (2006-07), Topalova (2007), Edmonds et al. (2010), Topalova (2010), and Gaddis and Pieters (2012).
} 
low-status women and falls for high-status women.

The analysis of heterogeneity, in combination with the findings of prior literature on the effects of the Indian trade reform, allows us to distinguish between three potential mechanisms: (a) changes in household income, (b) changes in relative female bargaining power, and (c) altered future labor market returns from daughters relative to sons. ${ }^{2}$ Topalova (2010) has shown that relative wages decreased in impacted industries and relative poverty increased in Indian districts more exposed to trade reform. ${ }^{3}$ To the extent that income shocks are linked to investments in children's health ${ }^{4}$ and parents' decisions about the number and the sex-composition of their children, ${ }^{5}$ we expect tariff cuts to influence fertility and sex ratios. Additionally, structural adjustments resulting from trade liberalization may change the relative demand for female labor, ${ }^{6}$ or the gender wage gap ${ }^{7}$ and, thus, influence fertility through changes in relative female bargaining power. Similarly, if female fetuses are selectively aborted due to the lower economic value of daughters relative to sons, any effect of trade liberalization on the demand for female labor could also influence the sex ratio at birth (Qian (2008)).

Using data from the National Sample Survey (NSS), we show that tariff declines result in a significant increase in adult employment for lower-caste women and upper-caste men. On the other hand, adult employment decreases for upper-caste women and lower-caste men, albeit insignificantly. These results suggest that differential changes in labor market returns by gender and social status are the most likely explanatory channel for our findings. Parents from socially disadvantaged groups are investing more in daughters in two ways. First, girls are more likely to be born, potentially due to reduced use of sexselective abortions. Secondly, they take better care of the daughters since, conditional on being born, infant mortality for low-status girls decreases. Low-status boys do not benefit equally because their potential

\footnotetext{
${ }^{2}$ More open trade may also influence relative commodity prices in an economy and, hence, consumption levels (Porto (2007)). Changes in the amount and the type of food (and nutrients) consumed by the mother and her children due to differences in dietary preferences across districts could affect child health outcomes, in general, and infant mortality, in particular (Cutler et al. (2006)).

${ }^{3}$ Although, using state-level data, Hasan et al. (2006-07) conclude that greater exposure to trade openness is not associated with slower reduction in poverty in rural India. For a more detailed discussion, we refer the reader to Topalova (2010).

${ }^{4}$ Strauss and Thomas (1998), Strauss and Thomas (2008), Case (2001), Case (2004), Paxson and Schady (2005)

${ }^{5}$ Edlund and Lee (2009), Almond et al. (2013)

${ }^{6}$ Katz and Murphy (1992), Kucera (2001), Kucera and Milberg (2000), Gaddis and Pieters (2012)

${ }^{7}$ Wood (1991), Black and Brainerd (2004)
} 
earning opportunities have not increased as much. ${ }^{8}$

We make a number of contributions. Most papers in the field of international economics have examined the effects of trade liberalization on industrial outcomes such as productivity, employment, and wages. ${ }^{9}$ We highlight that trade policy can also have substantial implications for less obvious outcomes such as fertility and child mortality. ${ }^{10}$ Moreover, we add to the extremely limited literature on the distributional effects of more open trade, especially along the gender dimension. ${ }^{11}$ Despite methodological shortcomings, existing papers suggests that trade openness has not unambiguously benefited everyone (Goldberg and Pavcnik (2007a)). However, the identities of "winners" and "losers" are not precisely known. Topalova (2010) finds that the slower decline in poverty caused by tariff cuts most affected the poorest sections of the Indian society. In addition, the decrease in education expenditure on children in response to the immediate change in family income affected girls more (Edmonds et al. (2010)). Our results paint a slightly different picture. We find that adult female employment increases and mortality of girls relative to boys decreases in lower-caste families. The losers, however, are also female, albeit at the other end of the social hierarchyfrom upper-caste, more educated, and relatively wealthy households. We show that (a) the labor market outcomes for men and women from different social strata have changed differentially, and (b) households are responding to this altered economic landscape via fertility and investments in children's human capital. Interestingly, we find that the results of Edmonds et al. (2010) exhibit substantial heterogeneity by caste: in districts more exposed to tariff cuts, the decrease in schooling they find is driven by upper-caste children; children from scheduled caste households are, in fact, more likely to be in school and less likely to work.

\footnotetext{
${ }^{8}$ This may also be due to limited occupational mobility for low-status men as suggested by Munshi and Rosenzweig (2009)). It is also possible that low-status parents strategically choose not to over-invest in their sons so that they continue to participate in the traditional occupational networks of lower-caste men (Munshi and Rosenzweig (2006)).

${ }^{9}$ Tybout (2003), Trefler (2004), Hanson (2007), Goldberg and Pavcnik (2007b), Goldberg and Pavcnik (2007a), Harrison et al. (2011), Kovak (2012)

${ }^{10}$ In a similar vein, Edmonds et al. (2010) and Kis-Katos and Sparrow (2011) examine the impact of trade policy on children's schooling and child labor in India and Indonesia, respectively.

${ }^{11}$ Since beginning work on this paper, we have become aware of another study, Chakraborty (2012), analyzing the impact of trade liberalization on sex ratios in India. Our paper differs from hers in a number of ways. First, she uses birth histories from the 1999 National Family Health Survey of India (NFHS), a much smaller dataset than ours, the 2002-2004 District-Level Household Survey of India (DLHS). Second, while her measure of trade exposure is similar to ours, she only includes tariffs in the manufacturing sector; we include tariffs in all traded industries, including agriculture, the main sector of employment for rural India. Finally, our empirical strategies differ significantly; we believe our empirical specifications and larger sample size allow us to better isolate the causal effect of trade liberalization on fertility outcomes.
} 
These distributional effects can play an important role in exacerbating or combating historical socioeconomic inequalities and, hence, it is crucial to take them into account while estimating the total costs and benefits of trade policies.

Second, our paper adds to the somewhat scarce literature on the determinants of discrimination against female children in several developing societies. While overall fertility and child mortality have decreased, the sex ratio at birth has sharply increased in many Asian countries, including India. A "preference" for sons relative to daughters is widely believed to be the underlying cause of prenatal and postnatal discrimination against girls, but credible explanations for this difference in valuation are limited, especially in the Indian context. ${ }^{12}$ Our finding that girls fare better (worse) in terms of mortality rates precisely in groups where the relative earning potential of women has improved (worsened) is consistent with the findings of Qian (2008) in the context of China, and emphasizes the economic roots of seemingly subjective discrimination.

Third, our fertility results underscore the fertility-sex ratio trade-off present in countries with a stronger valuation of sons (Anukriti (2013)). If son preference persists over time, ${ }^{13}$ parents may substitute less than perfectly between sons and daughters despite an increase in the relative benefit from girls. They may continue to have the desired number of sons but decrease prenatal (as well as postnatal) discrimination against girls, and hence, fertility may increase as the sex ratio at birth decreases, consistent with our results for low-status families. On the flip side, a decrease in the relative returns from girls, as we observe for high-status families, may enhance the use of sex-selective abortions, causing fertility to fall and the sex ratio at birth to rise.

Lastly, on the technical side, our ability to control for state-specific time trends and mother fixed-effects in the regression analysis makes our identification more robust than previous literature on the effects of tariff reforms on household and individual outcomes.

In Section 2, we provide a summary of the Indian trade reform. In Section 3, we outline our empirical methodology and describe the data. Section 4 presents the regression estimates, Section 5 discusses the un-

\footnotetext{
${ }^{12}$ Carranza (2012) is an exception.

${ }^{13}$ Abrevaya (2009), Almond and Edlund (2008), Almond et al. (2011), and Dubuc and Coleman (2007) find evidence for persistence in son preference among Asian immigrants to the United States, Canada, England, and Wales.
} 
derlying mechanisms, and Section 6 conducts some robustness checks. Section 7 provides a brief discussion and Section 8 concludes the paper.

\section{India's Trade Liberalization}

We analyze the effect of trade liberalization on household fertility decisions and children's health in the context of India's 1991 trade reform. Faced with a balance of payments crisis in August 1991, the Indian government embarked on several major economic reforms as conditions of an International Monetary Fund (IMF) bailout. Included among these requirements was a unilateral reduction in the overall level and the dispersion of import tariffs as well as the removal of non-tariff barriers (NTBs), such as import licensing.

The period after the IMF bailout, therefore, marks a sharp break in Indian trade policy. The maximum tariff fell immediately from 400 percent to 150 percent, with later revisions bringing the maximum tariff to approximately 45 percent by 1997 (Hasan et al. (2006-07)). Meanwhile, the average tariff fell from 80 percent in 1990 to 37 percent in 1996 and the standard deviation of tariffs declined by 50 percent (Topalova (2010)). NTBs also fell, with the proportion of goods subject to quantitative restrictions receding from 87 percent in 1987 to 45 percent by 1994 (Topalova (2010)).

In addition to the sharp decline in trade protection, the 1991 episode possesses several important features that are valuable for our analysis. Since the policy reform was imposed as part of the IMF bailout, the tariff cuts were largely unanticipated by firms and households in India. As other commentators have observed, the removal of trade barriers was implemented swiftly as a form of "shock-therapy" and was not part of any pre-existing development plan (Bhagwati (1993), Goyal (1996)). It is, therefore, unlikely that our results are driven by any adjustments in fertility in anticipation of these reforms.

The quick initiation of the liberalization episode also reduces concerns about industries with greater political influence or higher productivity shaping the structure of the tariff reform in a way that would undermine our empirical strategy (described in detail in the following section). Topalova (2007) finds that industry-level tariff changes are uncorrelated with several proxies of an industry's political influence prior to the Indian reform, such as the number of employees, proportion of skilled workers, and industrial concentration. Previous studies also find no correlation between an industry's future tariffs and its pro- 
ductivity before 1991 or productivity growth during 1989-1997 (Topalova (2004)). Finally, tariff changes through 1997 were spelled out in India's Eighth Five Year plan (1992-1997), suggesting little room for manipulation of tariffs based on political economy concerns during this time period.

It must be noted that, like Edmonds et al. (2010), we ignore changes in NTBs, primarily due to data availability issues. Thus, our results measure the effect of only one important dimension of the trade reform, i.e. the tariff cuts. The exclusion of NTBs is potentially harmful for our empirical strategy if the trends in NTBs were in the opposite direction as compared to tariffs. But as mentioned by Edmonds et al. (2010), there is a positive correlation in tariffs and NTBs during our sample period. Thus, our results are biased only to the extent that some of the effects we assign to tariff cuts may have instead been caused by the removal of NTBs. ${ }^{14}$

\section{Empirical Strategy}

\subsection{Measuring Exposure to Tariff Reduction}

The impact of trade liberalization on a developing economy, such as India, can be felt through many channels. The availability of cheaper imported final goods can be welfare-improving for consumers, while the reduction in tariffs on intermediate inputs can increase firm productivity. Although a decrease in consumer prices could certainly influence fertility behavior, this effect will be common across all households in India. On the other hand, an increase in supply of cheaper imported products that compete with domestic goods can reduce employment and wages at domestic firms. Like many other papers in the literature, our measure of tariff protection emphasizes this latter effect of trade openness on employment.

National tariff protection varies across industries and over time in India. Moreover, there is substantial heterogeneity in the industrial composition of Indian districts prior to 1991. Therefore, depending on their industrial composition of employment at the time of reform, some Indian districts experienced relatively larger reductions in trade protection than others. Following Topalova (2010) and others, our identification strategy relies on this comparison to estimate the causal effect of tariff reform.

\footnotetext{
${ }^{14}$ Edmonds et al. (2010) also argue that despite incomplete removal of NTBs by 1997, the volume of imports increased in response to tariffs cuts suggesting that the latter were a significant and important part of the reform.
} 
Specifically, we interact the national nominal ad-valorem tariff faced by industry $i$ in year $t$, tarif $f_{i t}$, with the share of employment in industry $i$ and district $d$ in 1991 , empshar $e_{i d}^{1991}$, to construct a measure of tariff for district $d$ in year $t$ :

$$
\text { tarif } f_{d t}=\sum_{i} \text { empshare }_{i d}^{1991} \times \operatorname{tariff} f_{i t}
$$

Since the employment shares are based on a district's industrial composition before the initiation of trade liberalization, our tariff measure is free of any endogenous changes in employment composition that take place due to the removal of tariff barriers.

Even though tariff cuts took place across a wide range of industries, certain industries, such as cereals and oilseeds production, were non-traded, i.e. only the government was allowed to be an importer of goods in these industries. ${ }^{15}$ Consequently, tarif $f_{d t}$ assigns a zero tariff to the non-traded industries for the entire time period. This implies that districts with higher levels of employment in the non-traded sector in 1991 will mechanically have lower tarif $f_{d t}$ (Hasan et al. (2006-07)). Since a large proportion of non-traded employment is in the cereal and oilseeds sectors, and workers in these industries tend to be poor rural farmers, this introduces a negative correlation between poverty and tarif $f_{d t}$.

Previous studies have addressed this concern by constructing a second measure of district tariffs that only depends on employment in traded industries (Hasan et al. (2006-07), Topalova (2007), Topalova (2010)). We follow the literature and create this measure as follows, where $e m p_{i d}^{1991}$ is the employment in a traded industry $i$ and district $d$ in 1991:

$$
\text { tradedtarif } f_{d t}=\frac{\sum_{i \in \text { traded }} e m p_{i d}^{1991} \times \text { tarif } f_{i t}}{\sum_{i \in \text { traded }} e m p_{i d}^{1991}}
$$

The only difference between the two measures of tariff protection in (1) and (2) is that the latter excludes employment in non-traded industries while constructing weights for industry-level tariffs. The traded tariff measure is, therefore, independent of the proportion of workers in the non-traded sector and is uncorrelated with initial poverty levels within a district.

\footnotetext{
${ }^{15}$ Other non-traded industries during our sample period were services, trade, transportation, and construction.
} 


\subsection{Data}

We use data from the second round of the District-Level Household Survey (DLHS-2) of India. The DLHS-2 surveyed 507,000 currently-married women (aged 15 - 44 years) from 620,000 households in 593 districts during March 2002 - October 2004. This survey includes a complete retrospective birth history for every woman interviewed, containing information on the month and the year of child's birth, birth order, age of the mother at birth, and the age at which the child died, if the child is deceased.

We focus our analysis on rural areas within Indian districts. Topalova (2010) finds an insignificant relationship between tariff protection and poverty in urban areas of Indian districts, which she attributes to pre-existing trends in poverty and the presence of other reforms in addition to trade liberalization that impacted urban areas. Due to concerns of simultaneous reforms and pre-existing trends in urban areas, we focus on rural areas only.

Since we focus on district as the geographical unit of interest, ideally we would like to know the district in which a birth takes place. However, DLHS-2 only includes district of residence identifiers at the time of survey. As a result, we assume that all births to a woman take place in her district of residence at the time of survey. This implicitly assumes that mothers do not migrate to a different district after initiating child-bearing. This is a reasonable assumption in this context since inter-district migration in India is low and mostly consists of women relocating as a result of marriage. In addition, this assumption is problematic

only if the measurement error induced by it varies, systematically, with our measures of district-level tariff protection. Later, in Section 6 we show that the tariff cuts had no significant effect on the gender and caste composition of in-migrants from other districts.

We restrict our sample to the 1987-1997 time period. There are two reasons for this. First, 1987 is the earliest year for which we have tariff data. Second, the tariff changes during 1992-1997 were spelled out in India's Eighth Five Year Plan, so they are unlikely to have been influenced by political economy decisions. After 1997, however, industry-level tariffs are negatively correlated with the industry's current productivity (Topalova (2004)), suggesting that these latter changes may be endogenous to an industry's performance. For this reason, we only focus on years up to 1997. Figure 1 shows the evolution of nominal national industry-level ad-valorem tariff during 1987-1997. Average tariff fell from about 95 percent in 1987 
to about 30 percent in 1997.

We impose three additional sample-selection criteria. First, we only include births for whom the mother's age at birth was between 13 and 40. Second, we exclude birth parities of 11 or higher. We use these restrictions due to the small number of births to women outside of the 13-40 age range and the small number of births with parity above 10. However, our results are not sensitive to the exclusion of these observations. The DLHS questionnaires were also administered to women who were visiting the household at the time of the survey. Since there is no information on their permanent district of residence, we exclude them from our analysis. Our final sample comprises 464,916 births to 269,661 women in 408 districts.

The district-level tariff data comes directly from Topalova (2010). Industry- and district-wise employment data comes from the 1991 Census of India while tariff data at the six-digit level was collected by Petia Topalova from the Indian Ministry of Finance publications. The rainfall data used later comes from the annual district-level precipitation time series created by Ram Fishman using Indian Meteorological Department database. Lastly, we use Rounds 43 (1987-88) and 55 (1999-00) of the Employment-Unemployment survey of the National Sample Survey (NSS) of India to examine the effects of tariff cuts on children's schooling and labor force participation, adult employment, and in-migration by caste and gender.

\subsection{Regression Framework}

The question of interest in this paper is how the removal of tariff barriers influences households' fertility decisions and children's health outcomes. In particular, we investigate whether reductions in tariff protection faced by a woman (based on her district of residence) impact the probability that she gives birth in a year, the sex ratio of these births, and their mortality rates. Our regression framework is similar to Edmonds et al. (2010) and Topalova (2010) and compares women (births) in districts that were more or less exposed to tariff cuts.

We start by reshaping the retrospective birth data to create a woman-year panel and construct a dummy variable, birth $h_{m d t}$, that equals one if a woman $m$ in district $d$ gives birth in year $t$, and is otherwise zero. Then, we estimate the following base specification using ordinary least-squares (OLS):

$$
\text { birth }_{m d t}=\beta_{0}+\beta_{1} \text { tariff } f_{d t}+\beta_{2} X_{m d t}+\gamma_{d}+\tau_{t}+\delta_{d} t+\epsilon_{m d t}
$$


The main regressor of interest, tarif $f_{d t}$, represents the level of tariff protection assigned to a women based on her district of residence. Although the variation in tarif $f_{d t}$ occurs at the district-level, we also control for a vector of individual covariates, $X_{m d t}$, that may impact the outcome variables, including indicators for a woman's age in year $t$, the number of previous births, the household's caste ${ }^{16}$ and religion. ${ }^{17}$ Inclusion of district fixed-effects, $\gamma_{d}$, controls for time-invariant differences across districts while year fixed-effects, $\tau_{t}$, control for any India-wide shocks that may influence our outcomes. The inclusion of year fixed-effects also highlights that our empirical strategy does not estimate the overall effect of trade liberalization on fertility, sex ratios at birth, or mortality, since any economy-wide impact on consumer prices or productivity will be captured by the year-effects. Since our data spans all years between 1987 and 1997, we also include linear district-specific time trends in our regressions.

The sex ratio and mortality regressions are run using the retrospective panel of births. The base OLS specification is similar to $(3)$ :

$$
y_{i m d t}=\beta_{0}+\beta_{1} \text { tarif } f_{d t}+\beta_{2} X_{i m d t}+\gamma_{d}+\tau_{t}+\delta_{d} t+\epsilon_{i m d t}
$$

where $i$ indexes a child born to mother $m$ in district $d$ and year $t$. For mortality regressions, the outcome is an indicator variable for whether a child dies before $Q$ months of birth, where we allow $Q$ to equal one, six, or twelve months. ${ }^{18}$ For the sex ratio regressions, the outcome is an indicator variable that equals one if the child is male, and zero otherwise. The remaining controls are the same as in (3).

Since a large majority (89 percent) of women in our sample report giving birth to more than one child during the time period we study, we also run specifications with mother fixed-effects:

$$
\begin{array}{r}
\text { birth } h_{m d t}=\beta_{0}+\beta_{1} \text { tariff } f_{d t}+\beta_{2} X_{m d t}+\tau_{t}+\phi_{m}+\delta_{d} t+\epsilon_{m d t} \\
y_{i m d t}=\beta_{0}+\beta_{1} \text { tariff } f_{d t}+\beta_{2} X_{i m d t}+\tau_{t}+\phi_{m}+\delta_{d} t+\epsilon_{i m d t}
\end{array}
$$

where $\gamma_{m}$ represents the mother fixed-effect and controls for all unobserved, time-invariant heterogeneity

\footnotetext{
${ }^{16}$ Caste categories are scheduled caste (SC), scheduled tribe (ST), other backward caste (OBC), and general caste.

${ }^{17}$ Religion categories are Hindu, Muslim, Sikh, Christian, and Others.

${ }^{18}$ Infant mortality is defined as death before age 1 , while child mortality usually refers to death before age 5 .
} 
across women that could influence her fertility decisions. $X_{m d t}$ and $X_{i m d t}$ now include just the indicators for number of previous births and woman's age in year $t$. By including mother fixed-effects, we are essentially comparing the birth outcomes for the same woman under different levels of tariff protection in her district. Our ability to control for district-specific time trends and mother fixed-effects makes our identification more robust than previous literature. A positive (negative) $\beta_{1}$ implies that tariff decline is associated with a decrease (increase) in the outcome of interest, relative to the national trend.

The coefficient $\beta_{1}$ is identified under the assumption that changes in our tariff measure are uncorrelated with district-specific, unobserved time-varying shocks (or mother-specific, unobserved time-varying shocks in (5)-(6)) that influence fertility, sex ratios, and infant mortality. Since we interact a district's pre-reform industrial composition with national changes in industry tariffs to construct tarif $f_{d t}$, any source of bias would have to be correlated with both pre-reform industrial composition and national tariff changes by industry. Like Topalova (2010), Edmonds et al. (2010) and others, we assume that this is not the case. Nevertheless, we test the validity of this assumption by checking that our results are robust to the inclusion of other observable district-specific, time-varying shocks, such as rainfall shocks.

For our sex ratio regressions, $t$ refers to the year of conception, instead of the year of birth. Since an ultrasound test, followed by an induced abortion, are believed to be the primary channel through which parents exercise control over the sex of their births in India during our sample period (Bhalotra and Cochrane (2010)), and these technologies are most effective and safe during the first or second trimesters of birth (Epner et al. (1998)), district-level tariff protection during the year of conception is more relevant for explaining the effect of trade reform on sex ratios at birth. We define the year of conception as the year nine months prior to the month of birth, thereby implicitly assuming that no birth is premature.

One concern is that tarif $f_{d t}$ may be correlated with the pre-reform size of a district's non-traded sector and, hence, correlated with its initial level of poverty. If this is the case, OLS estimates in specifications (3)-(6) will be biased. We deal with this issue by using traded tariff, $\operatorname{tradedtariff} f_{d t}$ as an instrument for tarif $f_{d t}$. Figure 2 plots both these measures for our sample period. Since non-traded industries are automatically assigned a zero tariff for all years, the average tariff measure is, by construction, substantially lower than the average traded tariff measure. While tradedtarif $f_{d t}$ declined from about 88 percent to 31 
percent, tarif $f_{d t}$ decreased from about 7 percent to 2 percent during 1987-1997. There is a significant correlation between the two measures (first-stage regression estimates presented later) and they both exhibit a sharp downward trend. ${ }^{19}$ Moreover, tradedtarif $f_{d t}$ is independent of the baseline proportion of workers in the non-traded sector and therefore, uncorrelated with initial poverty levels within a district. This validates the use of traded tariff as an instrument.

Next, we look at the time trends in fertility, the sex ratio at birth, and infant mortality in India during our study period. The total fertility rate declined from 4.1 in 1987 to 3.3 in 1997 (Figure 3). The malefemale sex ratio in the 0-6 age group has been rising rapidly (Figure 4), especially since the 1980s. Increased availability of technology for sex-selection combined with declining fertility and a strong preference for sons are widely believed to be the causes for this growing sex-imbalance in the child population. According to DLHS-2 data, under-5 mortality in rural India fell from 127 deaths per 1000 live births in 1987 to 95 deaths per 1000 live births in 1997. As Figure 5 shows, infant mortality has been declining over time. Mortality before age 1 is much higher than mortality during ages 1-4. Mortality for girls is larger during ages 1-4. It is important to keep in mind that our identification strategy does not estimate the causal impact of tariff reductions in explaining these aggregate trends. Instead, we estimate the effect of tariff reductions on deviations from the trend. Table 1 provides a description of the socio-economic characteristics of our sample.

\section{Results}

\section{$4.1 \quad$ Fertility}

We begin by looking at the effect of changes in district-level tariff exposure in a year on the probability that a woman gives birth in that year. ${ }^{20}$ Column (1) in Table 2 presents the baseline results controlling for district and year fixed-effects. In Column (2) we also control for mother's years of schooling, indicators for

\footnotetext{
${ }^{19}$ The only exception is an increase in tariffs from 1992 to 1993 . Due to measurement error concerns, we also run regressions that exclude the data for 1993. Our results remain the same and are available upon request.

${ }^{20}$ Throughout this paper, we use the term fertility to indicate probability of birth in a given year. A higher probability of birth does not necessarily imply higher completed fertility. It is possible that our results capture changes in the timing of births rather than changes in overall fertility levels.
} 
mother's age in that year, her number of previous births, and household's caste and religion. In Column (3) we add district-specific linear time trends. Finally, Columns (4) and (5) also control for mother fixed-effects. In all specifications, robust standard errors are clustered at the district level and district-level sampling weights are used. ${ }^{21}$

The OLS results in Panel A indicate a positive and significant relationship between our district-level tariff measure and the probability that a woman gives birth across all columns. These positive coefficients suggest that women in districts more exposed to trade liberalization (i.e. a relative decline in our tariff measure) witnessed a relative decrease in fertility. However, for reasons previously described, changes in the tariff measure utilized in Panel A may be negatively correlated with a district's initial poverty level. If women in initially poorer districts also experience relatively smaller declines in fertility over our time period for reasons unrelated to trade liberalization, OLS will overestimate the causal effect of tariff protection on fertility. We, therefore, instrument for our tariff protection measure using traded tariff protection, which is uncorrelated with the size of the non-traded sector, as previously argued. Panel B of Table 2 shows the firststage regression of a district's tariff measure on a district's traded tariff protection. In all specifications, traded tariff has a significant and strong first-stage impact on district tariff protection, indicating that traded tariff is a strong instrument for district tariff. ${ }^{22}$

When we use traded tariff as an instrument (Panels $\mathrm{C}$ and D of Table 2), district tariff protection in a year has a negative and largely significant effect on the probability that a woman gives birth in that year. The fact that our coefficient of interest changes sign when instrumenting for district tariff protection suggests that including non-traded industries in the tariff measure introduces a significant upward bias, likely due to the correlation between initial poverty and changes in the tariff measure. The reduced form coefficient of traded tariff is also negative throughout and significant (except in Column (4)).

The IV coefficients indicate that the Indian trade reform had a substantial effect on fertility - a woman living in a district that experienced the average decline in tariff protection of 7 percentage points was between 0.6 percentage points (Panel C, Column 1) and 1.7 percentage points (Panel C, Column 5) more

\footnotetext{
${ }^{21}$ The unweighted regressions yield very similar results, which are available upon request.

${ }^{22}$ The first stage F-statistic is large in all specifications.
} 
likely to give birth in a given year. ${ }^{23}$

\subsection{Sex Ratio at Birth}

Having established that a reduction in a district's relative tariff exposure leads to an increased probability of birth in rural India, we turn our attention to the sex-composition of these births. The sex ratio at birth (SRB) deviates from the natural SRB if female fetuses are terminated more frequently than male fetuses due to less prenatal care or sex-selective abortions. In India, prenatal sex-determination is illegal, but widely prevalent, leading to a large number of female fetuses being aborted. Bhalotra and Cochrane (2010) estimate that approximately 480,000 sex-selective abortions took place in India annually during 1995 2005. Trade liberalization can affect the SRB by (a) changing the demand for sex-selective abortions due to changes in the relative demand for sons, (b) changing the demand for sex-selective abortions due to changes in parents' ability to afford prenatal sex determination and abortion resulting from changes in income, (c) through income shocks which impact fetal viability differentially based on the sex of the fetus (Trivers and Willard (1973)), ${ }^{24}$ or (d) through greater access to sex-determination technology via imports of ultrasound machines, for example. ${ }^{25}$

Sex-determination can be effectively performed through an ultrasound test around 12 weeks of gestation or through amniocentesis around 8-9 weeks of gestation. If a mother has an induced abortion, it is likely to take place during the first or second trimester of pregnancy. This suggests that the relevant tariff variable to examine the effect of trade liberalization on the sex of a birth is not the tariff at the time of birth, but the tariff during the first two trimesters of pregnancy. Therefore, we use tariff in the district of birth in the year of conception as the explanatory variable for all sex ratio regressions.

Using the retrospective panel of births, Table 3 presents the results from OLS and IV regressions of

\footnotetext{
${ }^{23}$ Table A.1 in the Appendix presents the IV results for urban areas and we find a similar increase in the likelihood of birth in response to tariff cuts. Coefficients are negative and significant across all five specifications.

${ }^{24}$ The Trivers-Willard hypothesis suggests that negative shocks to the fetal environment make births less likely to be male.

${ }^{25}$ Changes in prenatal sex-determination technology, however, are likely to impact the entire country, or at least all districts within a state similarly. Since our measure of tariff protection varies at the district level, this channel is unlikely to explain our results.
} 
an indicator for male birth on district-level tariff during the year of conception. ${ }^{26}$ The OLS coefficients in Panel A show that a child born in a district with a relative decline in tariff protection during the year of conception is less likely to be a boy; but the effect is not significant at conventional levels. Panels B, C, and D present the IV regression estimates. The first stage coefficients of traded tariff are positive and highly significant throughout. The IV and reduced form coefficients of district tariff in the year of conception are always positive, but only significant when we include the mother fixed-effects in Columns (4) and (5). ${ }^{27}$ For a district with the average decline in tariffs of 7 percentage points, Column (4) in Panel C suggests that the likelihood of a male birth decreases by 2 percentage points. Thus, the reduction in trade protection seems to have caused some relative improvements in the probability of a female birth in rural Indian districts more exposed to tariff declines. ${ }^{28}$

The fact that we find significant results when we control for mother fixed-effects and not without them highlights the importance of time-invariant unobserved heterogeneity in factors that influence decisions about sex-selection. Apart from the monetary cost of prenatal sex-detection and sex-selective abortion, unobserved subjective son preference is likely to be an important factor in parents' decisions about sexselection. Although in specifications without mother fixed-effects we control for some observable socioeconomic characteristics that are likely to be correlated with son preference, for example religion, it is possible that they do not fully capture the unobserved heterogeneity across women. In Section 5.1, we present evidence for heterogeneity in the effects on the sex ratio at birth across socio-economic groups.

\subsection{Infant Mortality}

Next, we examine the effect of tariff decline on infant mortality. Following the same format as before, Table 4 presents results from OLS (Panel A) and IV regressions (Panels B and C) of indicators for whether a child dies within one, six, or twelve months of birth on district-level tariff protection. Across all specifications,

\footnotetext{
${ }^{26}$ Each cell indicates a separate regression. As before, all regressions use district-level sampling weights and robust standard errors are clustered at the district level.

${ }^{27}$ However, the coefficients for non-mother fixed-effects specifications are also significant when we use alternate levels of clustering, e.g. district-year. Here, we report results with more conservative standard errors, which in our case are obtained from clustering at the district level.

${ }^{28}$ Table A.1 in the Appendix shows that the effects on SRB in urban areas were insignificant even for the mother fixed-effects specification. Moreover, the coefficients are of the opposite sign as compared to the rural results.
} 
the coefficient estimates are negative, indicating that a larger decline in tariff protection within a district is associated with a relative increase in infant mortality within one, six, as well as twelve months of birth. However, our OLS and IV estimates lose significance at conventional levels when we add district-specific linear time trends to the regressions (except for mortality within 12 months).

The magnitude of coefficient estimates increases as we change our outcome variable from mortality within one month of birth to mortality within six months to twelve months of birth. The fact that we find significant results on mortality within the first month of birth for some specifications suggests that trade liberalization also influences parents' ability to invest in the health of a child while in-utero. ${ }^{29}$ However, the increase in the magnitude of the coefficients as we look at mortality within six and twelve months implies that trade liberalization prevents families from making the necessary investments in a child's health to prevent infant death even after birth. ${ }^{30}$

Moreover, the estimated effects are economically significant. For example, our coefficient estimate of -0.118 in Column (4), Panel C3 of Table 4 indicates that, relative to other districts, a district that experienced the average decline in tariff protection of 7 percentage points witnessed an increase in infant mortality within twelve months of birth of 0.8 percentage points - about a 9 percent increase with respect to the baseline (1987) mortality within a year of birth in all districts (9 percent).

In Table 5, we interact the tariff measure with a dummy for the child being male to test if the effect on mortality differs by child's sex. Previous research on the Trivers-Willard Hypothesis indicates that male children are less likely to survive relative to females in harsher environments (Almond and Edlund (2007)). If a decline in tariff protection increases poverty and decreases health investments in pregnant women or newborn children, we might expect trade liberalization to have a greater effect on mortality rates of male children. The main effect of our tariff measure suggests that there is a significant increase in mortality within twelve months of birth for girls. ${ }^{31}$ The coefficient of the interaction term is positive everywhere,

\footnotetext{
${ }^{29}$ Investments in health while in-utero are also likely to be affected by the tariff in the year of conception. In order to examine this channel, we also run regressions using tariff in the year nine months prior to the year of birth as the explanatory variable. The tariff coefficients are negative but not always significant and smaller in magnitude in comparison to the coefficients in Table 4.

${ }^{30}$ We find no significant effect on any mortality outcome for urban areas in Table A.1 in the Appendix.

${ }^{31}$ Similar results are obtained for mortality within one and six months of birth and are available upon request.
} 
suggesting a smaller effect on boys. However, the interaction term is significant only in Columns (4) and (5) that include mother fixed-effects. According to the coefficients in Column (4), in a district that experienced the average decline in tariff protection of 7 percentage points, girls witnessed an increase in infant mortality within twelve months of birth of 1.6 percentage points as opposed to boys for whom mortality within twelve months increased by a much lower 0.1 percentage points. These effects are consistent with prior evidence on postnatal neglect and discrimination in care against girls in India. To the extent that parents are able to exercise their preference for male children at the prenatal stage through sex-selection, an increase in sex-selective abortions can lead to a decline in relative female mortality (Lin et al. (2010)). But if poverty makes sex-selection less affordable, then we may expect the pattern we observe: a lower sex ratio at birth, but higher relative female mortality. As we show in the next section, there is substantial heterogeneity in the effects on infant mortality across socio-economic groups.

\section{Mechanisms}

So far, our results suggest that relative declines in tariffs in rural Indian districts lead to a significant increase in the probability of birth and the likelihood of these births being female, although the latter effect is significant only for the mother fixed-effects specification. Moreover, the likelihood that a child dies within one, six or twelve months of birth significantly increases. Next, we explore the mechanisms underlying these results.

We attempt to distinguish between three potential channels: 1) poverty, 2) female bargaining power, and 3) relative returns from daughters. Unfortunately, our data does not contain information on household income, consumption expenditure, wages, or mother's labor force participation status, making it difficult to directly test for the aforementioned causal channels. As a second best approach, we examine heterogeneity in effects by the socio-economic characteristics of mothers to provide suggestive evidence about the causal mechanisms underlying our main results. This approach is based on the premise that the three channels mentioned above should affect our three outcome variables differently, thus helping us deduce the underlying mechanisms. Moreover, it is also possible that mechanisms differ across socio-economic groups. Before we proceed to the regression results, we first discuss the expected effect on our outcome variables through 
each of these three channels.

Topalova (2010) shows that districts more exposed to trade liberalization witnessed a relative increase in poverty. Households that suffer a negative income shock due to tariff cuts may be less able to afford modern birth control methods and sex-selective abortions, causing an increase in births, especially female births. ${ }^{32}$ In addition, the supply of free or subsidized contraception may decline if government finances decline as a result of trade liberalization. Moreover, if poverty impacts the probability that a child survives to adulthood or the likelihood that a child is male, households may choose to increase fertility if decisions about the number and the sex-composition of children are jointly made. Poverty can also lead to increases in infant mortality if families reduce investments in infant health as a result of a decline in income. Furthermore, if the additional girls born as a result of the increase in poverty and the resulting inability to plan fertility are viewed as "unwanted," we would expect the increase in infant mortality to be higher for daughters relative to sons. Thus, if the relative increase in poverty from trade reform is the underlying channel, we are likely to observe an increase in fertility, a decrease in the sex ratio at birth, and an increase in infant mortality, more so for girls. On the other hand, if poverty decreases as a result of trade reform, we expect the opposite effects, i.e. lower fertility, a higher sex ratio at birth, and lower infant mortality rates.

Aguayo-Tellez et al. (2010) show that a NAFTA-related decrease in tariffs increased intra-household bargaining power of women in Mexico. They believe this is due to two reasons. First, technology-upgrading by firms in response to trade liberalization makes physically demanding skills less important in blue-collar jobs. As a result, the relative wage and employment of women improves in blue-collar occupations, as shown by Juhn et al. (2012). Second, trade reform leads to growth which is concentrated in initially female-intensive industries, and thus benefits women in these industries relatively more if male and female labor are imperfect substitutes. If intra-household bargaining is the primary channel through which trade reform affects fertility and infant mortality, then we expect to see lower fertility due to higher opportunity cost of childbearing (Chiappori et al. (2002), Rosenzweig and Wolpin (1980)), and lower mortality due to higher relative income of mothers. However, it is not clear which direction the sex ratio at birth would

\footnotetext{
${ }^{32}$ Bhalotra and Cochrane (2010) show that wealthier families in India are more likely to practice sex-selection.
} 
change in. For a given degree of son preference, a higher opportunity cost of "unwanted" children for working mothers might cause greater sex-selection and, thus, result in higher sex ratios at birth. Women in the labor force may also have a lower search cost of accessing prenatal sex-determination and abortion.

Lastly, Munshi and Rosenzweig (2006) find that the new economic opportunities resulting from globalization are mainly benefitting lower-caste girls in India. Despite increases in returns to non-traditional white-collar occupations, lower-caste parents continue to educate their sons in local language schools (that lead to traditional blue-collar jobs) in order to continue benefitting from caste-based networks. However, historically, lower-caste girls have not participated in these caste-based occupational networks due to low labor market participation, and are, hence, not constrained by them. As a result, lower-caste parents continue to channel boys into traditional occupations despite higher returns in more modern jobs, but their daughters benefit as a result of these improved employment opportunities. In a similar vein, Jensen and Miller (2011) show that parents in rural India strategically try to prevent sons from migrating to urban areas to take advantage of better income opportunities because they want them to work on the farm. They find large gains in education for girls but not much for boys in response to greater employment opportunities in urban areas. They conclude that these results are driven by changes in returns (to parents) from sons and daughters. In our context, an increase in the relative demand for daughters, due to a relative increase in returns to parents from girls, would imply that lower-caste parents should now be more likely to give birth to daughters, who might also experience a decrease in mortality. In other words, the increase in female births in this scenario is driven by more "wanted" girls, unlike the poverty channel where more "unwanted" girls are born due to reduced affordability of sex-selection or lower opportunity cost of children. If the decrease in female mortality is sufficiently large, we will also observe an overall decrease in mortality across all births. The impact on the likelihood of birth depends on the extent to which parents substitute between sons and daughters in the short- and the long-run.

The following table summarizes the predictions discussed above. So far, our main findings appear consistent with the increased poverty channel, although the sex ratio at birth results are weak. Armed with these predictions, we now turn to analyzing heterogeneity in our effects across three dimensions household's caste, mother's education level, and household's wealth index - to distinguish between these 
potential mechanisms.

\begin{tabular}{lccc}
\hline & \multicolumn{3}{c}{ Expected effect on: } \\
\cline { 2 - 4 } Channel & Birth & Sex Ratio at Birth & Mortality \\
\hline$\uparrow$ Poverty & + & - & + \\
$\uparrow$ Female bargaining power & - & Unclear & - \\
$\uparrow$ Relative returns to daughters & Unclear & - & - \\
\hline
\end{tabular}

\section{$5.1 \quad$ Heterogeneous Effects}

We begin our examination of heterogeneity with a household's caste. We divide our sample into four categories - scheduled caste (SC), scheduled tribe (ST), other backward caste (OBC), and general caste - and interact our tariff variable with indicators for these categories. Table 6 presents these results for the birth dummy, male birth dummy, and mortality within twelve months. General caste is the omitted category. Panel A shows that the main effect of tariff in the year of birth is positive (insignificant in Column (3)) while the interaction terms for SC, ST, and OBC mothers are negative, highly significant, and larger in magnitude than the main effect. This implies that lower-caste women experience a significantly larger increase in the probability of birth relative to upper-caste mothers. Thus, our overall findings for fertility seem to be driven mainly by higher fertility for lower-caste mothers. There are no significant differences in our sex ratio results across caste groups, however.

The fertility effects are consistent with either the poverty or the returns channel working for the lowercaste households. Scheduled and other backward castes have historically been more economically and socially disadvantaged in India. A relative increase in poverty levels is, therefore, likely to affect them more strongly than upper-caste households. But, as the mortality results show, births to general caste mothers are significantly more likely to die due to tariff cuts while births to lower-caste mothers have significantly lower likelihood of death. The interaction coefficients for SC mothers are larger in magnitude, significant, and of the opposite sign as compared to the main effect. This pattern is inconsistent with the increased 
poverty channel. ${ }^{33}$ Moreover, when we separate the effect on mortality by child's sex in Table 7 , we find that the lower mortality results for SCs and OBCs are completely driven by girls. Upper-caste girls, on the other hand, experience a rise in mortality.

In Table 8 we repeat the same exercise by mother's education level. We divide women into three categories - uneducated women, those with 1-5 years of schooling, and women with more than 5 years of schooling. Panel A shows that there is no effect on the likelihood of birth for mothers with more than primary education. But, births increased significantly and the probability that these births are male decreased significantly for uneducated mothers. For mortality within a year of birth, we observe a similar pattern as our caste results. For uneducated mothers, there is a relative decrease in mortality, whereas more educated mothers experience an increase. When we split the mortality results by child's sex in Table 9 , we find a pattern somewhat similar to Table 7. Although both boys and girls born to uneducated mothers experience a relative decrease in mortality whereas those born to mothers with more than primary education experience a relative increase in mortality, the effects are larger for girls. To the extent that lower-caste women are likely to have a lower educational attainment, these results together highlight the possibility of gains for girls born to lower-status parents from tariff reductions through a relative increase in returns on the labor market.

To further explore the mechanisms, we next examine how our effects vary by the wealth index of the household. DLHS combines information on ownership of durables, type of toilet facility, cooking fuel, housing, source of lighting, and drinking water to calculate a standard of living score for each household. On the basis of these scores, households are divided into three categories: low, medium, and high standard of living (SLI) households. Ideally, we would like to know the household wealth score for each year in our sample period. But, unfortunately, since we create our birth and woman panels retrospectively from a single cross-section, we know a household's wealth category only at the time of survey. To the extent that trade reform affects standards of living, the wealth index variable is not exogenous. However, if most households

\footnotetext{
${ }^{33}$ Another possibility is that lower-caste households actually bene fit from tariff cuts and experience a relative decrease in poverty which lowers mortality. But in that case, we would not expect to see their fertility increase, which is what we find in Panel A.
} 
move within a wealth category, and not across categories (e.g. a high-SLI family becoming low-SLI) due to tariff reduction, this comparison is still informative. With these caveats in mind, Panel A in Table 10 shows that the higher fertility and the decreased likelihood of a birth being male are mainly driven by low-SLI families. In fact, medium- and high-SLI families experience a significant decrease in the likelihood of birth. Unlike the weak effects in Table 3, there is a significant decrease in the sex ratio at birth for relatively poorer, low-SLI families and a slightly significant increase for the high-SLI households in response to the tariff decline. The magnitude of this effect is remarkably similar across all specifications and suggests that in districts with an average relative decline in tariff of 7 percentage points, the sex ratio at birth decreases by 1.5 percentage points in low-SLI households. Yet again, the mortality results suggest that the effects for low-SLI women are potentially driven by the returns channel. Mortality decreases for births to low-SLI women relative to high-SLI families. For latter, the main effect is an increase in mortality. When we split the mortality results by child's sex in Table 11, we find that both boys and girls born to high-SLI mothers experience a relative increase in mortality whereas those born to low-SLI mothers experience a significant decrease in mortality relatively. But unlike the caste results in Table 7 , the difference between the results for boys and girls is not remarkable.

\subsection{Supporting Evidence}

Next, we utilize data from NSS to shed further light on potential mechanisms. If a relative change in the returns from children on the labor market is an underlying channel for our previous findings, we also expect differential changes in educational investments by socio-economic status in response to tariff cuts. To test this, we follow Edmonds et al. (2010) and estimate the effect of tariff cuts on schooling and child labor outcomes of 10-14 year old children in rural Indian districts using the 43rd (1987-88) and the 55th (1999-00) rounds of the NSS Employment-Unemployment survey. Edmonds et al. (2010) find that schooling increased and child labor declined at a slower rate in districts that were relatively more exposed to tariff cuts. We extend their analysis and examine heterogeneity in these outcomes by the caste of the household. ${ }^{34}$ Since the 43rd round does not distinguish between OBC and general castes, we divide the sample into three

\footnotetext{
${ }^{34}$ The NSS does not provide information on mother's education or the household wealth status.
} 
categories - SC, ST, and the rest. Table 12 presents the IV estimates for the effects of tariff reform on an indicator for the child being in school $(S c h o o l)$ and five categories of work. Work is an indicator for a child's principal activity status being work-related ${ }^{35}$, irrespective of her school attendance status. Work only indicates that the child's principal activity is work and she does not attend school. Market work implies that the child works as a regular salaried/ wage employee, a casual wage laborer, in a household enterprise (farm or non-farm), or as a beggar. Domestic work indicates that the child's principal activity is domestic work. Lastly, Idle refers to children who neither work nor attend school.

Table 12 shows that the estimates presented in Edmonds et al. (2010) exhibit substantial heterogeneity by caste and are consistent with our previous findings. Panel $\mathrm{A}^{36}$ shows that $\mathrm{SC}$ children in districts relatively more exposed to tariff reform are significantly more likely to be in school, relative to children from OBC and general castes. The overall effect on schooling for SC children is also positive. In addition, Columns (2) - (4) show that SC children are less likely to work, both relative to the excluded category as well as overall, as tariffs decrease. We also observe a significant decrease in the likelihood of an SC child being Idle in response to the reform. On the other hand, general and OBC children are significantly less likely to be in school when tariffs decrease relatively in their districts. However, the effects on work categories for these non-SC and non-ST children are not significant. These results are consistent with tariff declines resulting in a relative increase in the returns from lower-caste children, relative to general and OBC children. However, further disaggregation of the sample by child sex in Panels B and C does not reveal differential effects for SC boys and girls.

In addition, we assess the relative returns channel by examining the effect of tariff cuts on adult employment in a manner similar to Table 4 in Edmonds et al. (2010). These results are presented in Table 13. The outcome variable is the number of days worked in the last year. Column (1) shows that tariff declines are associated with a significant decrease in the number of days worked for SC and ST men relative to non-SC and non-ST men. Overall, the latter group experiences a significant increase in the

\footnotetext{
${ }^{35}$ This includes the following categories of work: regular salaried/ wage employee, casual wage laborer, begging, work in a household enterprise, and domestic work.

${ }^{36}$ In Table 12 Panel A, we do not control for the sex of the child since it is also affected by the tariff cuts. However, the results remain the same when we control for child sex.
} 
number of days spent in wage work in response to tariff cuts, but the total effect for SC men is not large. On the other hand, in Column (2), there is a significant increase in the number of days worked for SC and ST women, relative to other women as well as overall, as tariffs decrease. For non-SC and non-ST women we observe a decrease in employment, albeit the coefficient is not significant. These results are consistent with trade liberalization increasing (decreasing) the returns for lower-caste (upper-caste) females, relative to males, in turn causing lower-caste (upper-caste) parents to give birth to more (fewer) girls and investing more (less) in them.

\section{Robustness}

Although prior literature on Indian trade liberalization (Topalova (2010), Edmonds et al. (2010)) shows that there is no significant factor mobility in response to tariff cuts, we explicitly check for endogenous sorting by gender and caste. We cannot use DLHS data for this exercise since it only reports a woman's district of residence at the time of survey. Consequently, we use NSS data to estimate the effect of tariff cuts on the caste- and gender-composition of a district's in-migrants ${ }^{37}$ using the same empirical strategy as in Section 5.2. These instrumental-variable estimates are reported in Table 14. There is no significant change in the share of female in-migrants and low-caste female in-migrants in a district due to the tariff reform (Rows 1 and 2). The same is also true for the share of short-run migrants (i.e. those who have moved within the past ten years) in Rows 3 and 4 of Table 14.

Although we include district-specific linear time trends in all regressions, a potential concern with our identification strategy is the presence of other time-varying district-specific omitted variables. Since our tariff exposure index varies at the district-year level, we cannot include district-year fixed-effects to prevent this omitted variable bias. Instead, we re-estimate all specifications by controlling for district-level annual rainfall shocks as a further check of robustness. Annual fluctuations in rainfall are an important determinant of economic outcomes in agriculture-dependent developing countries, such as India. ${ }^{38}$ We define rainfall

\footnotetext{
${ }^{37}$ In-migrants are individuals whose district of residence at the time of survey is different from their last place of usual residence (i.e. a place where the person has stayed continuously for a period of six months or more).

${ }^{38}$ Paxson (1992), Rosenzweig and Wolpin (1993), Townsend (1994), Jayachandran (2006).
} 
shock as an indicator variable that is equal to one if the annual rainfall in a district deviates by more than 30 percent from its historic annual mean precipitation, and zero otherwise. The point estimates on tariff measures in all specifications remain consistent with our previous results (with similar signs, magnitudes, and significance). These results are available upon request.

\section{Discussion}

To sum up, we see substantial differences in how trade liberalization has affected women and children across social strata. Broadly, we find that low socioeconomic status women experience an increase in fertility which is driven by more female births. Since we also observe a relative decrease in mortality for their daughters, we interpret this as a higher demand for daughters by low-status families. The same does not hold for high-status women. There is some evidence that they have fewer children, driven by fewer

girls, and we find strong evidence that girls born to high-status mothers fare worse in terms of higher mortality. Mortality rates for boys, however, do not seem to be significantly affected by the trade reform, irrespective of their parents' socio-economic status.

Thus, there appears to be a strong gender component to the effects of trade liberalization. If tariff reforms have improved earning opportunities for women in blue-collar occupations, as recent literature suggests, we would expect the gains to be derived by girls born to low-status families. We find some suggestive evidence that low-caste women work more and low-caste men work less relative to upper-caste women and men when tariffs decreases. To the extent that upper-caste and more educated women in India are less likely to participate in blue-collar occupations, we do not expect girls in high-status families to benefit from the new labor market opportunities in relatively blue-collar jobs as much as low-status women. Moreover, if returns from more skilled jobs have increased mainly for men in India, high-status families will prefer to have more sons. As supporting evidence, we find that there is an increase in the number of days worked for non-SC and non-ST men in districts experiencing a relative decrease in tariffs.

The effects of trade reform on fertility and child health outcomes that we find do not suggest that there has been an increase in the relative bargaining power for women. Lastly, the apparent increase in valuation of girls in low-status families and decrease in high-status families in response to trade reform can also be 
due to differential returns from children on the marriage market instead of or in addition to returns on the labor market (Edlund and Lee (2009)).

\section{Conclusions}

This paper analyzes whether India's trade liberalization, beginning in 1991, affected fertility, infant mortality, and sex ratios at birth. To identify the impact of this trade policy shock, we compare rural districts more exposed to tariff cuts to rural districts less exposed to tariff cuts. Previous research using a similar empirical strategy finds that districts subject to greater reductions in tariffs experience slower declines in poverty as well as slower increases in school enrollment ((Topalova (2010), Edmonds et al. (2010)). We find that lower-caste, less educated, and less wealthy women in districts with a higher relative trade reform exposure are more likely to give birth and these births are more likely to be female. Moreover, infant mortality (within one, six, and twelve months of birth) decreases for these girls. In contrast, girls born to upper-caste, more educated, and wealthier mothers experience relatively higher mortality. They are also less likely to be born.

It is important to emphasize that these results do not suggest that more open trade leads to overall increases or decreases in fertility, sex ratios, or infant mortality. ${ }^{39}$ However, our results do confirm that removal of trade barriers has important distributional consequences along these dimensions, especially for girls. Data limitations prevent us from conducting a more rigorous analysis of the exact channels through which tariff cuts affect individuals' fertility decisions and investments in children, but we highlight the potential role played by differential returns from children that vary by socio-economic status and child sex.

\footnotetext{
${ }^{39}$ We note again that this paper only examines the effect of tariff reductions and ignores the removal of NTBs.
} 


\section{References}

Abrevaya, J. (2009): "Are There Missing Girls in the United States? Evidence from Birth Data," American Economic Journal: Applied Economics, 1, 1-34.

Aguayo-Tellez, E., J. Airola, And C. Juhn (2010): "Did Trade Liberalization Help Women? The Case of Mexico in the 1990s," NBER Working Paper 16195.

Almond, D. And L. EdLund (2007): "Trivers-Willard at Birth and One Year: Evidence from US Natality Data 1983-2001," Proceedings of the Royal Society B, 274, 2491-2496.

(2008): "Son Biased Sex Ratios in the US 2000 Census," Proceedings of the National Academy of Sciences of the United States of America, 105, 5681-5682.

Almond, D., L. Edlund, And K. Milligan (2011): "O Sister, Where Art Thou? The Role of Son Preference and Sex Choice: Evidence from Immigrants to Canada," NBER Working Paper 15391.

Almond, D., H. Li, And S. Zhang (2013): "Land Reform and Sex Selection in China," NBER Working Paper 19153.

Anukriti, S. (2013): "The Fertility-Sex Ratio Trade-off: Unintended Consequences of Financial Incentives," BC Department of Economics Working Paper No. 827.

Bhagwati, J. (1993): India in Transition: Freeing the Economy, Oxford: Oxford University Press.

Bhalotra, S. And T. Cochrane (2010): "Where Have All the Young Girls Gone? Identification of Sex Selection in India," IZA Discussion Paper No. 5381.

Black, S. E. And E. Brainerd (2004): "Importing Equality? The Impact of Globalization on Gender Discrimination," Industrial and Labor Relations Review, 57, 540-559.

Carranza, E. (2012): "Soil Endowments, Production Technologies and Missing Women in India," World Bank Policy Research Working Paper 5974.

Case, A. (2001): "Health, Income, and Economic Development," Annual World Bank Conference on Development Economics, 221-241.

(2004): Does Money Protect Health Status? Evidence from South African Pensions, University of Chicago Press, vol. Perspectives on the Economics of Aging, chap. 8, 287-312, 1 ed.

Chakraborty, T. (2012): "Impact of Industrialization on Relative Female Survival: Evidence from Trade Policies," Unpublished manuscript.

Chiappori, P.-A., B. Fortin, And G. Lacroix (2002): "Marriage Market, Divorce Legislation, and Household Labor Supply," Journal of Political Economy, 110, 37-72.

Cutler, D., A. Deaton, And A. Lleras-Muney (2006): "The Determinants of Mortality," Journal of Economic Perspectives, 20, 97-120. 
Dubuc, S. And D. Coleman (2007): "An Increase in the Sex Ratio of Births to India-born Mothers in England and Wales: Evidence for Sex-Selective Abortion," Population and Development Review, 32 , $328-332$.

Edlund, L. And C. Lee (2009): "Son Preference, Sex Selection and Economic Development: Theory and Evidence from South Korea," Columbia University Department of Economics Discussion Paper No. 0910-04.

Edmonds, E. V., N. Pavcnik, And P. Topalova (2010): "Trade Adjustment and Human Capital Investments: Evidence from Indian Tariff Reform," American Economic Journal: Applied Economics, 2, $42-75$.

Epner, J. E. G., H. S. Jonas, And D. L. Seckinger (1998): "Late-term Abortion," The Journal of American Medical Association, 280, 724-729.

Gaddis, I. And J. Pieters (2012): "Trade Liberalization and Female Labor Force Participation: Evidence from Brazil," IZA Discussion Paper No. 6809.

Goldberg, P. And N. PAvCnik (2007a): "Distributional Effects of Globalization in Developing Countries," Journal of Economic Literature, XLV, 39-82.

Goldberg, P. K. And N. Pavcnik (2007b): Globalization and Poverty, University of Chicago Press and the NBER, chap. The Effects of the Colombian Trade Liberalization on Urban Poverty.

Goyal, S. K. (1996): "Political Economy of India's Economic Reforms," Institute for Studies in Industrial Development (ISID) Working Paper.

Gupta, P. And U. Kumar (2008): "Trade Liberalization and Wage Inequality: Evidence From India," Review of Development Economics, 12, 291-311.

Hanson, G. H. (2007): Globalization and Poverty, University of Chicago Press and the NBER, chap. Globalization, Labor Income, and Poverty in Mexico, 417-456.

Harrison, A., J. Mclaren, and M. McMillan (2011): "Recent Perspectives on Trade and Inequality," World Bank Policy Research Working Paper 5754.

Hasan, R., D. Mitra, And B. P. Ural (2006-07): "Trade Liberalization, Labor-Market Institutions, and Poverty Reduction: Evidence from Indian States," Indian Policy Forum, 3, 71-122.

Jayachandran, S. (2006): "Selling Labor Low: Wage Responses to Productivity Shocks in Developing Countries," Journal of Political Economy, 114.

Jensen, R. And N. Miller (2011): "Keepin' 'em Down on the Farm: Old Age Security and Strategic Underinvestment in Children," Unpublished manuscript.

Juhn, C., G. Ujhelyi, And C. Villegas-Sanchez (2012): "Men, Women, and Machines: How Trade Impacts Gender Inequality," NBER Working Paper 18106.

Katz, L. F. And K. M. Murphy (1992): "Changes in Relative Wages 1963 - 1987: Supply and Demand Factors," Quarterly Journal of Economics, 107, 35-78. 
Kis-Katos, K. And R. Sparrow (2011): "Child Labor and Trade Liberalization in Indonesia," Journal of Human Resources, 46, 722-49.

KovaK, B. K. (2012): "Regional Effects of Trade Reform: What is the Correct Measure of Liberalization?" Unpublished manuscript, Carnegie Mellon University.

KucERA, D. (2001): "Foreign Trade of Manufactures and Men and Women's Employment and Earnings in Germany and Japan," International Review of Applied Economics, 15, 129-149.

Kucera, D. And W. Milberg (2000): "Gender Segregation and Gender Bias in Manufacturing Trade Expansion: Revisiting the Wood Asymmetry," World Development, 28, 1191-1210.

Lin, M.-J., J.-T. LiU, AND N. Qian (2010): "More Missing Women, Fewer Dying Girls: The Impact of Abortion on Sex Ratios at Birth and Excess Female Mortality in Taiwan," NBER Working Paper 14541.

Munshi, K. And M. Rosenzweig (2006): "Traditional Institutions Meet the Modern World: Caste, Gender, and Schooling Choice in a Globalizing Economy," American Economic Review, 96, 1225-1252.

(2009): "Why is Mobility in India so Low? Social Insurance, Inequality, and Growth," Unpublished manuscript.

Paxson, C. (1992): "Using Weather Variability to Estimate the Response of Savings to Transitory Income in Thailand," The American Economic Review, 82.

Paxson, C. H. And N. Schady (2005): "Child Health and Economic Crisis in Peru," The World Bank Economic Review, 19, 203-223.

Porto, G. G. (2007): "Estimating Household Responses to Trade Reforms: Net Consumers and Net Producers in Rural Mexico," World Bank Policy Research Working Paper.

QIan, N. (2008): "Missing Women and the Price of Tea in China: The Effect of Sex-Specific Income on Sex Imbalance," The Quarterly Journal of Economics, 123, 1251-1285.

Rosenzweig, M. And K. Wolpin (1980): "Life-Cycle Labor Supply and Fertility: Causal Inferences from Household Models," Journal of Political Economy, 88.

(1993): "Credit Market Constraints, Consumption Smoothing, and the Accumulation of Durable Production Assets in Low-Income Countries: Investments in Bullocks in India," Journal of Political Economy, 101.

Strauss, J. A. And D. Thomas (1998): "Health, Nutrition, and Economic Development," Journal of Economic Literature, 36, 766-817.

(2008): Health over the Life Course, Elsevier, vol. 4 of Handbook of Development Economics, chap. 54, 3375-3474.

Topalova, P. (2004): "Trade Liberalization on Productivity: The Case of India," International Monetary Fund Working Paper. 
(2007): Trade Liberalization, Poverty, and Inequality: Evidence from Indian Districts, University of Chicago Press, vol. Globalization and Poverty, chap. 7.

(2010): "Factor Immobility and Regional Impacts of Trade Liberalization: Evidence on Poverty from India," American Economic Journal: Applied Economics, 2, 1-41.

Townsend, R. (1994): "Risk and Insurance in Village India," Econometrica, 62.

Trefler, D. (2004): "The Long and Short of the Canada-U.S. Free Trade Agreement," American Economic Review, 94, 870-895.

Trivers, R. And D. Willard (1973): "Natural Selection of Parental Ability to Vary the Sex Ratio of Offspring," Science, 179, 90-92.

Tyвout, J. R. (2003): Handbook of International Trade, Malden, MA: Blackwell, chap. Plant- and FirmLevel Evidence on "New" Trade Theories, 388-415.

Wood, A. (1991): "North-South trade and female labour in manufacturing: An asymmetry," Journal of Development Studies, 27, 168-189. 


\section{Figures}

Figure 1: Average Industry-level Tariff

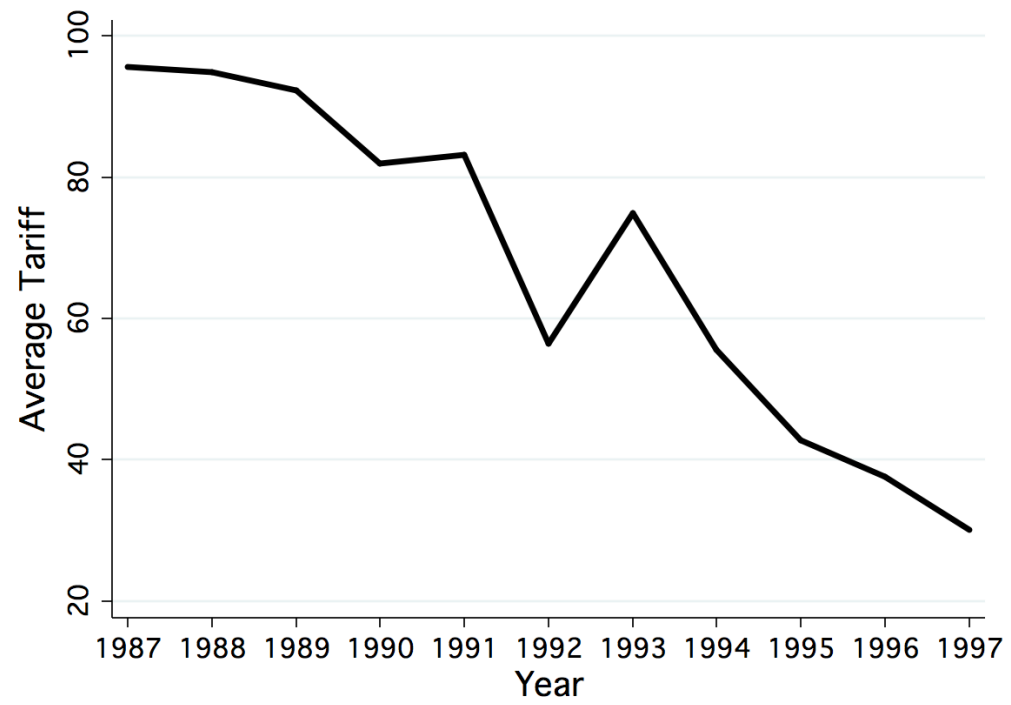

NOTE: This figure plots the yearly averages of nominal, national, industry-level ad-valorem tariffs using data provided by Petia Topalova. 
Figure 2: Average District-level Tariff and Traded Tariff, by Year

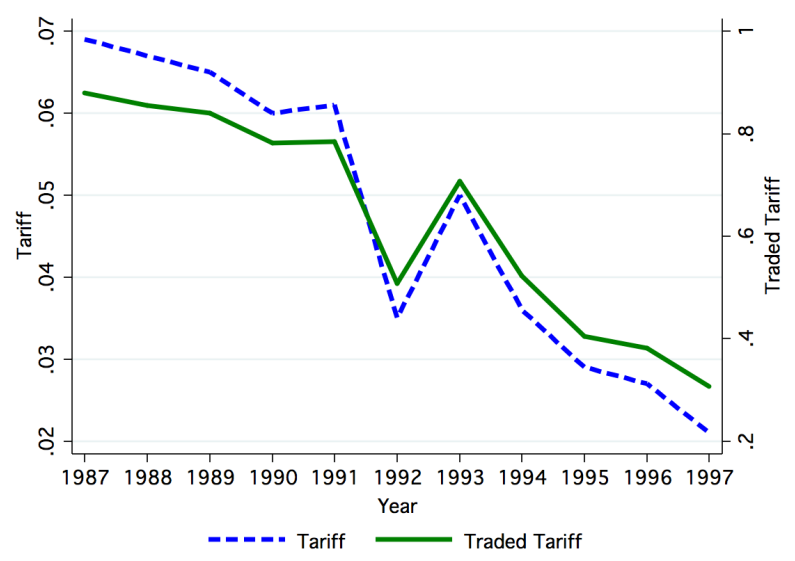

NOTE: This figure plots the yearly averages of the district-level tariff and traded tariff measures used in this paper. Districtyear data on both measures was provided by Petia Topalova. Tariff is constructed as the district-specific employment weighted sum of industry-specific national tariffs. Traded tariff is constructed in a similar way, but only uses employment in traded sectors within a district. District-level employment shares in 1991 are used as weights. More details are available in Section 3.1 .

Figure 3: Total Fertility Rate in India, by Year

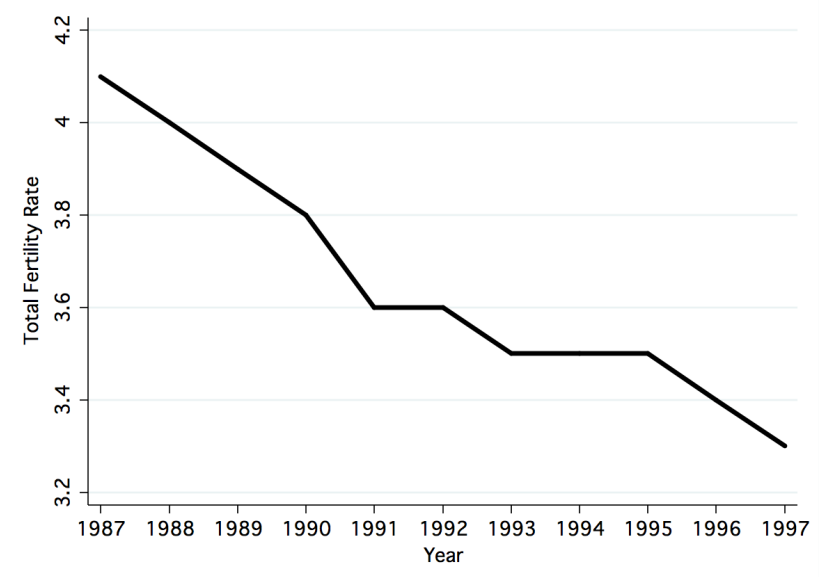

SOURCE: Ministry of Health and Family Welfare, Govt. of India (accessed from Indiastat) 
Figure 4: Child Sex Ratio (0-6) in India, by Year

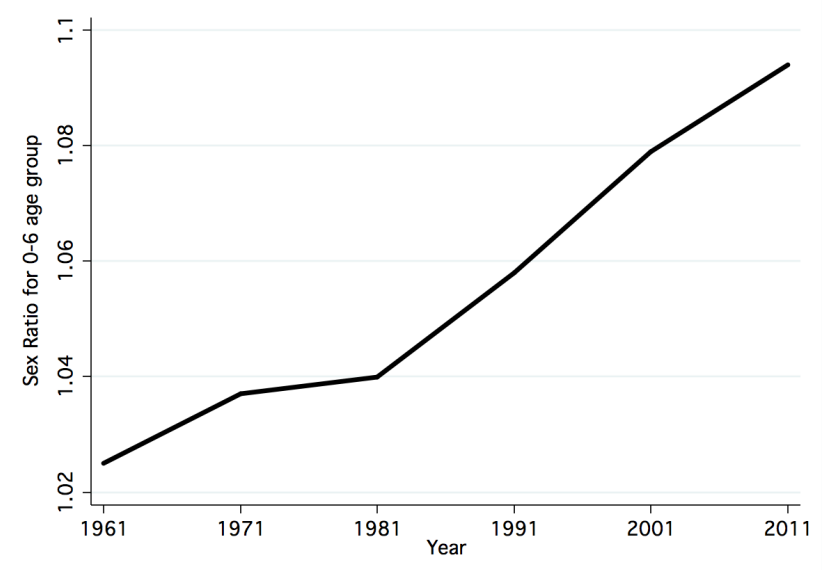

SOURCE: Census of India

Figure 5: Infant mortality in Rural India, by Year of Birth and Sex

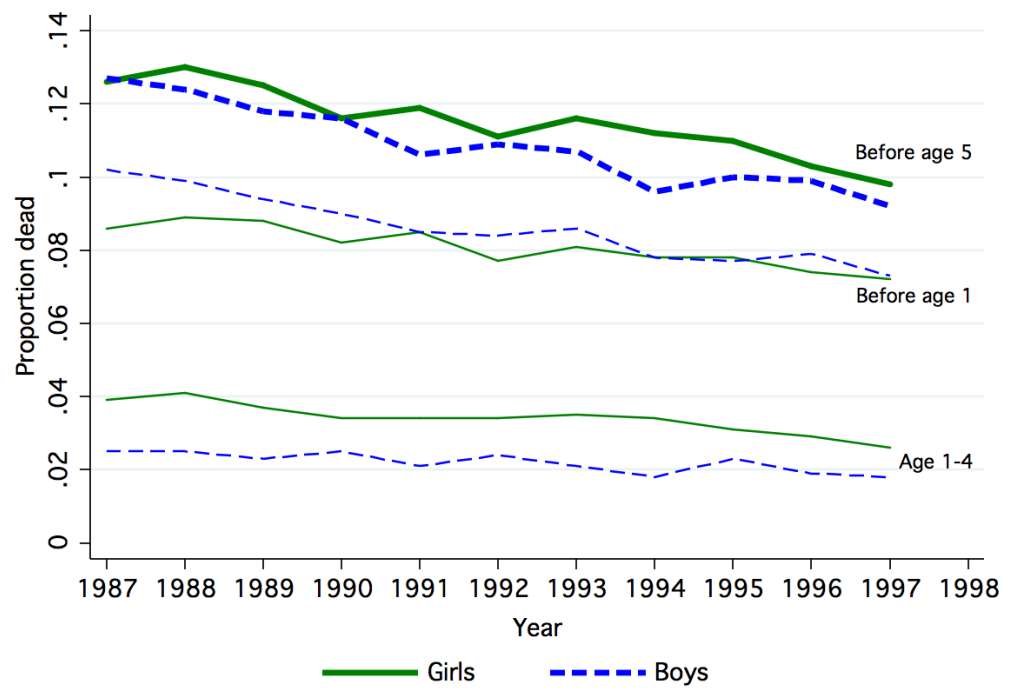

NOTE: This figure plots the average proportion of children who died before age 1, during ages 1-4 and before age 5 , by year of birth and sex. All-India sample weights used. Data source is DLHS (2002-04). 


\section{Tables}

Table 1: Summary Statistics for the Rural Sample, 1987 and 1997

\begin{tabular}{lcc}
\hline Variable & 1987 & 1997 \\
\hline Panel of Births & & \\
Birth is male & 0.517 & 0.521 \\
Parity of birth & 2.34 & 2.96 \\
Mother's age at birth & 21.04 & 23.28 \\
Mother's years of schooling & 1.90 & 2.51 \\
Hindu & 0.78 & 0.77 \\
Muslim & 0.09 & 0.10 \\
Sikh & 0.03 & 0.02 \\
Christian & 0.07 & 0.08 \\
Scheduled Caste & 0.18 & 0.19 \\
Scheduled Tribe & 0.19 & 0.22 \\
Other Backward Caste & 0.38 & 0.38 \\
Died within one month of birth & 0.06 & 0.05 \\
Died within 6 months of birth & 0.08 & 0.06 \\
Died within 12 months of birth & 0.09 & 0.07 \\
Low HH Wealth Index & 0.60 & 0.67 \\
Medium HH Wealth Index & 0.30 & 0.25 \\
High HH Wealth Index & 0.10 & 0.08 \\
N(births) & 31,356 & 48,755 \\
\hline Panel of Women & & \\
Birth & 0.22 & 0.18 \\
N(women) & 139,478 & 269,347 \\
\hline N(districts) & 408 & 408 \\
\hline
\end{tabular}

NOTES: This table presents summary statistics for the earliest (1987) and the latest (1997) years included in our rural sample. All regressions include every year during 1987-1997. 
Table 2: The Effect of Tariff Reduction on the Probability of Birth

\begin{tabular}{lccccc}
\hline & $(1)$ & $(2)$ & $(3)$ & $(4)$ & $(5)$ \\
\hline A. OLS & & & & & \\
Tariff in YOB & $0.129^{* * *}$ & $0.104^{* * *}$ & $0.069^{* *}$ & $0.581^{* * *}$ & $0.478^{* * *}$ \\
& {$[0.031]$} & {$[0.030]$} & {$[0.030]$} & {$[0.109]$} & {$[0.104]$} \\
B. First Stage & & & & & \\
Traded Tariff in YOB & $0.217^{* * *}$ & $0.217^{* * *}$ & $0.212^{* * *}$ & $0.212^{* * *}$ & $0.208^{* * *}$ \\
& {$[0.031]$} & {$[0.031]$} & {$[0.030]$} & {$[0.030]$} & {$[0.029]$} \\
F-stat & 48.16 & 48.19 & 49.14 & 49.86 & 50.92 \\
C. IV & & & & & \\
Tariff in YOB & -0.081 & $-0.118^{* *}$ & $-0.163^{* * *}$ & -0.108 & $-0.244^{*}$ \\
& {$[0.054]$} & {$[0.055]$} & {$[0.061]$} & {$[0.118]$} & {$[0.130]$} \\
D. Reduced form & & & & & \\
Traded Tariff in YOB & $-0.018^{*}$ & $-0.026^{* * *}$ & $-0.035^{* * *}$ & -0.023 & $-0.051^{* *}$ \\
& {$[0.010]$} & {$[0.010]$} & {$[0.010]$} & {$[0.025]$} & {$[0.025]$} \\
N & $1,857,834$ & $1,857,834$ & $1,857,834$ & $1,857,834$ & $1,857,834$ \\
\hline District FE & $\mathrm{x}$ & $\mathrm{x}$ & $\mathrm{x}$ & & \\
Year FE & $\mathrm{x}$ & $\mathrm{x}$ & $\mathrm{x}$ & $\mathrm{x}$ & $\mathrm{x}$ \\
Covariates & & $\mathrm{x}$ & $\mathrm{x}$ & $\mathrm{x}$ & $\mathrm{x}$ \\
District-specific linear trends & & & & $\mathrm{x}$ & $\mathrm{x}$ \\
Mother FE & & & & & $\mathrm{x}$ \\
\hline
\end{tabular}

NOTES: YOB stands for the year of birth. Each cell constitutes a separate regression. Columns (2) - (5) include indicators for mother's age at birth and number of previous births. Columns (2) and (3) also include mother's years of schooling and household's religion and caste dummies. Robust standard errors are in brackets and have been clustered at the district level. All regressions use district-level sampling weights. ${ }^{* * *} 1 \%, * * 5 \%, * 10 \%$. 
Table 3: The Effect of Tariff Reduction on Probability that a Birth is Male

\begin{tabular}{|c|c|c|c|c|c|}
\hline & (1) & $(2)$ & $(3)$ & (4) & $(5)$ \\
\hline \multicolumn{6}{|l|}{ A. OLS } \\
\hline Tariff in YOC & $\begin{array}{c}0.078 \\
{[0.050]}\end{array}$ & $\begin{array}{c}0.080 \\
{[0.050]}\end{array}$ & $\begin{array}{c}0.084 \\
{[0.053]}\end{array}$ & $\begin{array}{c}0.035 \\
{[0.101]}\end{array}$ & $\begin{array}{c}0.055 \\
{[0.106]}\end{array}$ \\
\hline \multicolumn{6}{|l|}{ B. First Stage } \\
\hline Traded Tariff in YOC & $\begin{array}{c}0.201^{* * *} \\
{[0.031]}\end{array}$ & $\begin{array}{c}0.201^{* * *} \\
{[0.031]}\end{array}$ & $\begin{array}{c}0.196^{* * *} \\
{[0.030]}\end{array}$ & $\begin{array}{c}0.182^{* * *} \\
{[0.028]}\end{array}$ & $\begin{array}{c}0.178^{* * *} \\
{[0.027]}\end{array}$ \\
\hline $\begin{array}{l}F \text {-stat } \\
\text { C. IV }\end{array}$ & 42.45 & 42.47 & 43.02 & 42.44 & 42.34 \\
\hline Tariff in YOC & $\begin{array}{c}0.097 \\
{[0.066]}\end{array}$ & $\begin{array}{c}0.097 \\
{[0.066]}\end{array}$ & $\begin{array}{c}0.107 \\
{[0.070]}\end{array}$ & $\begin{array}{c}0.314^{* * *} \\
{[0.113]}\end{array}$ & $\begin{array}{c}0.356^{* * *} \\
{[0.127]}\end{array}$ \\
\hline \multicolumn{6}{|l|}{ D. Reduced form } \\
\hline Traded Tariff in YOC & $\begin{array}{c}0.019 \\
{[0.014]}\end{array}$ & $\begin{array}{c}0.020 \\
{[0.014]}\end{array}$ & $\begin{array}{c}0.021 \\
{[0.015]}\end{array}$ & $\begin{array}{c}0.057^{* *} \\
{[0.025]}\end{array}$ & $\begin{array}{c}0.063^{* *} \\
{[0.028]}\end{array}$ \\
\hline $\mathrm{N}$ & 449,065 & 449,065 & 449,065 & 449,065 & 449,065 \\
\hline District FE & $\mathrm{x}$ & $\mathrm{x}$ & $\mathrm{x}$ & & \\
\hline Year FE & $\mathrm{x}$ & $\mathrm{x}$ & $\mathrm{x}$ & $\mathrm{x}$ & $\mathrm{x}$ \\
\hline Covariates & & $\mathrm{x}$ & $\mathrm{x}$ & $\mathrm{x}$ & $\mathrm{x}$ \\
\hline District-specific linear trends & & & $\mathrm{x}$ & & $\mathrm{x}$ \\
\hline Mother FE & & & & $\mathrm{x}$ & $\mathrm{x}$ \\
\hline
\end{tabular}

NOTES: YOC stands for the year of conception - defined as the year nine months prior to the month of birth. Each cell constitutes a separate regression. Columns (2) - (5) include indicators for mother's age at birth and number of previous births. Columns (2) and (3) also include mother's years of schooling and household's religion and caste dummies. Robust standard errors are in brackets and have been clustered at the district level. All regressions use district-level sampling weights. ${ }^{* * *}$ $1 \%,{ }^{*} * 5 \%, * 10 \%$. 
Table 4: The Effect of Tariff Reduction on Infant Mortality

\begin{tabular}{|c|c|c|c|c|c|}
\hline Mortality in 1 month & (1) & $(2)$ & $(3)$ & $(4)$ & $(5)$ \\
\hline \multicolumn{6}{|l|}{ A1. OLS } \\
\hline Tariff in YOB & $\begin{array}{c}-0.035^{* *} \\
{[0.016]}\end{array}$ & $\begin{array}{c}-0.041^{* *} \\
{[0.016]}\end{array}$ & $\begin{array}{l}-0.025 \\
{[0.017]}\end{array}$ & $\begin{array}{l}-0.023 \\
{[0.039]}\end{array}$ & $\begin{array}{l}-0.013 \\
{[0.041]}\end{array}$ \\
\hline \multicolumn{6}{|l|}{ B1. Reduced form } \\
\hline Traded Tariff in YOB & $\begin{array}{l}-0.009 \\
{[0.006]}\end{array}$ & $\begin{array}{l}-0.011^{*} \\
{[0.006]}\end{array}$ & $\begin{array}{l}-0.007 \\
{[0.006]}\end{array}$ & $\begin{array}{l}-0.015 \\
{[0.011]}\end{array}$ & $\begin{array}{l}-0.010 \\
{[0.011]}\end{array}$ \\
\hline \multicolumn{6}{|l|}{ C1. IV } \\
\hline Tariff in YOB & $\begin{array}{l}-0.045 \\
{[0.028]}\end{array}$ & $\begin{array}{c}-0.052^{*} \\
{[0.029]}\end{array}$ & $\begin{array}{l}-0.036 \\
{[0.030]}\end{array}$ & $\begin{array}{c}-0.080^{*} \\
{[0.047]}\end{array}$ & $\begin{array}{l}-0.058 \\
{[0.047]}\end{array}$ \\
\hline \multicolumn{6}{|l|}{ Mortality in 6 months } \\
\hline \multicolumn{6}{|l|}{ A2. OLS } \\
\hline Tariff in YOB & $\begin{array}{c}-0.046^{* *} \\
{[0.018]}\end{array}$ & $\begin{array}{c}-0.054^{* * *} \\
{[0.019]}\end{array}$ & $\begin{array}{l}-0.031 \\
{[0.019]}\end{array}$ & $\begin{array}{l}-0.036 \\
{[0.043]}\end{array}$ & $\begin{array}{l}-0.018 \\
{[0.044]}\end{array}$ \\
\hline \multicolumn{6}{|l|}{ B2. Reduced form } \\
\hline Traded Tariff in YOB & $\begin{array}{c}-0.011^{*} \\
{[0.007]}\end{array}$ & $\begin{array}{c}-0.013^{*} \\
{[0.007]}\end{array}$ & $\begin{array}{l}-0.008 \\
{[0.007]}\end{array}$ & $\begin{array}{l}-0.020 \\
{[0.012]}\end{array}$ & $\begin{array}{l}-0.014 \\
{[0.013]}\end{array}$ \\
\hline \multicolumn{6}{|l|}{ C2. IV } \\
\hline Tariff in YOB & $\begin{array}{c}-0.055^{*} \\
{[0.033]}\end{array}$ & $\begin{array}{l}-0.064^{*} \\
{[0.033]} \\
\end{array}$ & $\begin{array}{l}-0.040 \\
{[0.035]} \\
\end{array}$ & $\begin{array}{c}-0.106^{* *} \\
{[0.054]}\end{array}$ & $\begin{array}{l}-0.080 \\
{[0.055]} \\
\end{array}$ \\
\hline \multicolumn{6}{|l|}{ Mortality in 12 months } \\
\hline \multicolumn{6}{|l|}{ A3. OLS } \\
\hline Tariff in YOB & $\begin{array}{c}-0.052^{* *} \\
{[0.020]}\end{array}$ & $\begin{array}{c}-0.063^{* * *} \\
{[0.021]}\end{array}$ & $\begin{array}{c}-0.038^{*} \\
{[0.022]}\end{array}$ & $\begin{array}{l}-0.041 \\
{[0.046]}\end{array}$ & $\begin{array}{l}-0.019 \\
{[0.046]}\end{array}$ \\
\hline \multicolumn{6}{|l|}{ B3. Reduced form } \\
\hline Traded Tariff in YOB & $\begin{array}{c}-0.014^{*} \\
{[0.007]}\end{array}$ & $\begin{array}{c}-0.016^{* *} \\
{[0.008]}\end{array}$ & $\begin{array}{l}-0.010 \\
{[0.008]}\end{array}$ & $\begin{array}{l}-0.022 \\
{[0.013]}\end{array}$ & $\begin{array}{l}-0.016 \\
{[0.013]}\end{array}$ \\
\hline \multicolumn{6}{|l|}{ C3. IV } \\
\hline Tariff in YOB & $\begin{array}{c}-0.067^{*} \\
{[0.036]} \\
\end{array}$ & $\begin{array}{c}-0.076^{* *} \\
{[0.037]} \\
\end{array}$ & $\begin{array}{l}-0.051 \\
{[0.038]} \\
\end{array}$ & $\begin{array}{c}-0.118^{* *} \\
{[0.058]}\end{array}$ & $\begin{array}{l}-0.091 \\
{[0.058]} \\
\end{array}$ \\
\hline \multicolumn{6}{|l|}{ First Stage } \\
\hline Traded Tariff in YOB & $\begin{array}{c}0.207^{* * *} \\
{[0.032]}\end{array}$ & $\begin{array}{c}0.207^{* * *} \\
{[0.032]}\end{array}$ & $\begin{array}{c}0.201^{* * *} \\
{[0.030]}\end{array}$ & $\begin{array}{c}0.185^{* * *} \\
{[0.028]}\end{array}$ & $\begin{array}{c}0.180^{* * *} \\
{[0.027]}\end{array}$ \\
\hline F-stat & 42.85 & 42.88 & 43.88 & 43.14 & 43.44 \\
\hline $\mathrm{N}$ & 473,430 & 473,430 & 473,430 & 473,430 & 473,430 \\
\hline District FE & $\mathrm{x}$ & $\mathrm{x}$ & $\mathrm{x}$ & & \\
\hline Year FE & $\mathrm{x}$ & $\mathrm{x}$ & $\mathrm{x}$ & $\mathrm{x}$ & $\mathrm{x}$ \\
\hline Covariates & & $\mathrm{x}$ & $\mathrm{x}$ & $\mathrm{x}$ & $\mathrm{x}$ \\
\hline District-specific linear trends & & & $\mathrm{x}$ & & $\mathrm{x}$ \\
\hline Mother FE & & & & $\mathrm{x}$ & $\mathrm{x}$ \\
\hline
\end{tabular}

NOTES: YOB stands for the year of birth. Each cell constitutes a separate regression. All regressions include indicators for mother's age at birth and number of previous births. Columns (2) - (5) include indicators for mother's age at birth and number of previous births. Columns (2) and (3) also include mother's years of schooling and household's religion and caste dummies. Robust standard errors are in brackets and have been clustered at the district level. All regressions use district-level sampling weights. ${ }^{* * *} 1 \%, * * 5 \%, * 10 \%$. 
Table 5: IV Estimates for Infant Mortality: By Child's Gender

\begin{tabular}{lccccc}
\hline Mortality in 12 months & $(1)$ & $(2)$ & $(3)$ & $(4)$ & $(5)$ \\
\hline Tariff in YOB * Boy & 0.071 & 0.063 & 0.065 & $0.212^{* * *}$ & $0.214^{* * *}$ \\
& {$[0.046]$} & {$[0.046]$} & {$[0.046]$} & {$[0.066]$} & {$[0.067]$} \\
Tariff in YOB & $-0.104^{* *}$ & $-0.109^{* *}$ & $-0.085^{*}$ & $-0.226^{* * *}$ & $-0.200^{* * *}$ \\
& {$[0.044]$} & {$[0.044]$} & {$[0.045]$} & {$[0.068]$} & {$[0.068]$} \\
$\mathrm{N}$ & 473,430 & 473,430 & 473,430 & 473,430 & 473,430 \\
\hline District FE & $\mathrm{x}$ & $\mathrm{x}$ & $\mathrm{x}$ & & \\
Year FE & $\mathrm{x}$ & $\mathrm{x}$ & $\mathrm{x}$ & $\mathrm{x}$ & $\mathrm{x}$ \\
Covariates & & $\mathrm{x}$ & $\mathrm{x}$ & $\mathrm{x}$ & $\mathrm{x}$ \\
District-specific linear trends & & & $\mathrm{x}$ & & $\mathrm{x}$ \\
Mother FE & & & & $\mathrm{x}$ & $\mathrm{x}$ \\
\hline
\end{tabular}

NOTES: YOB stands for the year of birth. Each column constitutes a separate regression. Columns (2) - (5) include indicators for mother's age at birth and number of previous births. Columns (2) and (3) also include mother's years of schooling and household's religion and caste dummies. The main effect of Boy is included in all specifications, but not reported. Robust standard errors are in brackets and have been clustered at the district level. All regressions use district-level sampling weights. *** $1 \%, * * 5 \%, * 10 \%$. 
Table 6: IV Estimates: By Caste

\begin{tabular}{|c|c|c|c|}
\hline A. Birth $=1$ & (1) & $(2)$ & $(3)$ \\
\hline Tariff in $\mathrm{YOB} * \mathrm{SC}$ & $\begin{array}{c}-0.449^{* * *} \\
{[0.096]}\end{array}$ & $\begin{array}{c}-0.362^{* * *} \\
{[0.085]}\end{array}$ & $\begin{array}{c}-0.326^{* * *} \\
{[0.082]}\end{array}$ \\
\hline Tariff in YOB $*$ ST & $\begin{array}{c}-0.730^{* * *} \\
{[0.147]}\end{array}$ & $\begin{array}{c}-0.731^{* * *} \\
{[0.142]}\end{array}$ & $\begin{array}{c}-0.793^{* * *} \\
{[0.151]}\end{array}$ \\
\hline Tariff in $\mathrm{YOB} * \mathrm{OBC}$ & $\begin{array}{c}-0.250^{* * *} \\
{[0.077]}\end{array}$ & $\begin{array}{c}-0.211^{* * *} \\
{[0.069]}\end{array}$ & $\begin{array}{c}-0.145^{* *} \\
{[0.063]}\end{array}$ \\
\hline Tariff in YOB & $\begin{array}{c}0.191^{* *} \\
{[0.078]}\end{array}$ & $\begin{array}{l}0.126^{*} \\
{[0.072]}\end{array}$ & $\begin{array}{c}0.059 \\
{[0.075]}\end{array}$ \\
\hline $\mathrm{N}$ & $1,857,834$ & $1,857,834$ & $1,857,834$ \\
\hline \multicolumn{4}{|l|}{ B. $B o y=1$} \\
\hline Tariff in YOC * SC & $\begin{array}{c}0.031 \\
{[0.138]}\end{array}$ & $\begin{array}{c}0.035 \\
{[0.138]}\end{array}$ & $\begin{array}{c}0.010 \\
{[0.138]}\end{array}$ \\
\hline Tariff in $\mathrm{YOC}^{*} \mathrm{ST}$ & $\begin{array}{c}0.083 \\
{[0.154]}\end{array}$ & $\begin{array}{c}0.081 \\
{[0.154]}\end{array}$ & $\begin{array}{c}0.123 \\
{[0.158]}\end{array}$ \\
\hline Tariff in $\mathrm{YOC} * \mathrm{OBC}$ & $\begin{array}{l}-0.036 \\
{[0.113]}\end{array}$ & $\begin{array}{l}-0.034 \\
{[0.113]}\end{array}$ & $\begin{array}{l}-0.061 \\
{[0.112]}\end{array}$ \\
\hline Tariff in YOC & $\begin{array}{c}0.093 \\
{[0.097]}\end{array}$ & $\begin{array}{c}0.092 \\
{[0.097]}\end{array}$ & $\begin{array}{c}0.110 \\
{[0.101]}\end{array}$ \\
\hline $\mathrm{N}$ & 449,065 & 449,065 & 449,065 \\
\hline \multicolumn{4}{|l|}{ C. Mortality in 12 months } \\
\hline Tariff in $\mathrm{YOB} * \mathrm{SC}$ & $\begin{array}{c}0.248^{* * *} \\
{[0.081]}\end{array}$ & $\begin{array}{c}0.247^{* * *} \\
{[0.080]}\end{array}$ & $\begin{array}{c}0.207^{* * *} \\
{[0.079]}\end{array}$ \\
\hline Tariff in $\mathrm{YOB} * \mathrm{ST}$ & $\begin{array}{l}-0.127 \\
{[0.085]}\end{array}$ & $\begin{array}{l}-0.131 \\
{[0.086]}\end{array}$ & $\begin{array}{l}-0.073 \\
{[0.079]}\end{array}$ \\
\hline Tariff in $\mathrm{YOB} * \mathrm{OBC}$ & $\begin{array}{c}0.138^{* *} \\
{[0.058]}\end{array}$ & $\begin{array}{c}0.136^{* *} \\
{[0.058]}\end{array}$ & $\begin{array}{c}0.085 \\
{[0.058]}\end{array}$ \\
\hline Tariff in YOB & $\begin{array}{c}-0.136^{* * *} \\
{[0.052]}\end{array}$ & $\begin{array}{c}-0.142^{* * *} \\
{[0.052]}\end{array}$ & $\begin{array}{c}-0.103^{*} \\
{[0.053]}\end{array}$ \\
\hline $\mathrm{N}$ & 473,430 & 473,430 & 473,430 \\
\hline District FE & $\mathrm{x}$ & $\mathrm{x}$ & $\mathrm{x}$ \\
\hline Year FE & $\mathrm{x}$ & $\mathrm{x}$ & $\mathrm{x}$ \\
\hline Covariates & & $\mathrm{x}$ & $\mathrm{x}$ \\
\hline District-specific linear trends & & & $\mathrm{x}$ \\
\hline
\end{tabular}

NOTES: YOB stands for the year of birth. YOC stands for the year of conception. General caste households are the excluded group. The main effects of SC, ST, and OBC are included in all regressions but not reported. Columns (2)-(3) include indicators for mother's age at birth and number of previous births. Column (2) also includes mother's years of schooling and household's religion dummies. Robust standard errors are in brackets and have been clustered at the district level. All regressions use district-level sampling weights. $* * * 1 \%, * * 5 \%, * 10 \%$. 
Table 7: IV Estimates for Infant Mortality: By Caste and Child's Sex

\begin{tabular}{lcc}
\hline Mortality in 12 months & Girls & Boys \\
\hline Tariff in YOB * SC & $0.334^{* * *}$ & 0.097 \\
& {$[0.110]$} & {$[0.100]$} \\
Tariff in YOB * ST & -0.059 & -0.074 \\
& {$[0.111]$} & {$[0.103]$} \\
Tariff in YOB * OBC & $0.216^{* * * *}$ & -0.028 \\
& {$[0.078]$} & {$[0.078]$} \\
Tariff in YOB & $-0.167^{* *}$ & -0.050 \\
& {$[0.069]$} & {$[0.072]$} \\
N & 227,881 & 245,549 \\
\hline District FE & $\mathrm{x}$ & $\mathrm{x}$ \\
Year FE & $\mathrm{x}$ & $\mathrm{x}$ \\
Covariates & $\mathrm{x}$ & $\mathrm{x}$ \\
District-specific linear trends & $\mathrm{x}$ & $\mathrm{x}$ \\
\hline
\end{tabular}

NOTES: YOB stands for the year of birth. General caste households are the excluded group. The main effects of SC, ST, OBC are included in all regressions but not reported. All regressions include indicators for mother's age at birth, number of previous births, mother's years of schooling and household's religion dummies. Robust standard errors are in brackets and have been clustered at the district level. All regressions use district-level sampling weights. ${ }^{* * *} 1 \%,{ }^{*} * 5 \%,{ }^{*} 10 \%$. 
Table 8: IV Estimates: By Mother's Education

\begin{tabular}{|c|c|c|c|}
\hline A. Birth $=1$ & (1) & $(2)$ & $(3)$ \\
\hline Tariff in YOB * Uneducated & $\begin{array}{c}-0.138^{* *} \\
{[0.067]}\end{array}$ & $\begin{array}{c}-0.396^{* * *} \\
{[0.069]}\end{array}$ & $\begin{array}{c}-0.338^{* * *} \\
{[0.067]}\end{array}$ \\
\hline Tariff in YOB $* 1-5$ years & $\begin{array}{c}0.309^{* * *} \\
{[0.081]}\end{array}$ & $\begin{array}{c}0.102 \\
{[0.065]}\end{array}$ & $\begin{array}{l}0.109^{*} \\
{[0.065]}\end{array}$ \\
\hline Tariff in YOB & $\begin{array}{l}-0.080 \\
{[0.060]}\end{array}$ & $\begin{array}{c}0.060 \\
{[0.053]}\end{array}$ & $\begin{array}{c}0.002 \\
{[0.056]}\end{array}$ \\
\hline $\mathrm{N}$ & $1,354,769$ & $1,354,769$ & $1,354,769$ \\
\hline \multicolumn{4}{|l|}{ B. $B o y=1$} \\
\hline Tariff in YOC $*$ Uneducated & $\begin{array}{c}0.305^{* *} \\
{[0.143]}\end{array}$ & $\begin{array}{c}0.292^{* *} \\
{[0.142]}\end{array}$ & $\begin{array}{l}0.267^{*} \\
{[0.142]}\end{array}$ \\
\hline Tariff in YOC $* 1-5$ years & $\begin{array}{l}-0.152 \\
{[0.188]}\end{array}$ & $\begin{array}{l}-0.161 \\
{[0.187]}\end{array}$ & $\begin{array}{l}-0.159 \\
{[0.187]}\end{array}$ \\
\hline Tariff in YOC & $\begin{array}{l}-0.091 \\
{[0.125]}\end{array}$ & $\begin{array}{l}-0.082 \\
{[0.124]}\end{array}$ & $\begin{array}{l}-0.066 \\
{[0.129]}\end{array}$ \\
\hline $\mathrm{N}$ & 277,601 & 277,601 & 277,601 \\
\hline \multicolumn{4}{|l|}{ C. Mortality in 12 months } \\
\hline Tariff in YOB * Uneducated & $\begin{array}{c}0.207^{* * *} \\
{[0.066]}\end{array}$ & $\begin{array}{c}0.258^{* * *} \\
{[0.067]}\end{array}$ & $\begin{array}{c}0.214^{* * *} \\
{[0.064]}\end{array}$ \\
\hline Tariff in YOB $* 1-5$ years & $\begin{array}{l}-0.068 \\
{[0.071]}\end{array}$ & $\begin{array}{l}-0.044 \\
{[0.071]}\end{array}$ & $\begin{array}{l}-0.052 \\
{[0.071]}\end{array}$ \\
\hline Tariff in YOB & $\begin{array}{c}-0.173^{* * *} \\
{[0.056]}\end{array}$ & $\begin{array}{c}-0.216^{* * *} \\
{[0.058]}\end{array}$ & $\begin{array}{c}-0.174^{* * *} \\
{[0.059]}\end{array}$ \\
\hline $\mathrm{N}$ & 290,653 & 290,653 & 290,653 \\
\hline District FE & $\mathrm{x}$ & $\mathrm{x}$ & $\mathrm{x}$ \\
\hline Year FE & $\mathrm{x}$ & $\mathrm{x}$ & $\mathrm{x}$ \\
\hline Covariates & & $\mathrm{x}$ & $\mathrm{x}$ \\
\hline District-specific linear trends & & & $\mathrm{x}$ \\
\hline
\end{tabular}

NOTES: YOB stands for the year of birth. YOC stands for the year of conception. Women with more than 5 years of education are the excluded group. The sample is restricted to women above age 20 at the time of survey. The main effects of education groups are included in all regressions but not reported. Columns (2)-(3) include indicators for mother's age at birth and number of previous births. Column (2) also include household's caste and religion dummies. Robust standard errors are in brackets and have been clustered at the district level. All regressions use district-level sampling weights. ${ }^{* * *} 1 \%,{ }^{* *} 5 \%$, $* 10 \%$. 
Table 9: IV Estimates for Infant Mortality: By Mother's Education and Child's Sex

\begin{tabular}{lcc}
\hline Mortality in 12 months & Girls & Boys \\
\hline Tariff in YOB * Uneducated & $0.292^{* * *}$ & $0.140^{*}$ \\
& {$[0.084]$} & {$[0.078]$} \\
Tariff in YOB * 1-5 years & -0.063 & -0.050 \\
& {$[0.109]$} & {$[0.102]$} \\
Tariff in YOB & $-0.177^{* *}$ & $-0.164^{* *}$ \\
& {$[0.076]$} & {$[0.075]$} \\
N & 139,491 & 151,162 \\
\hline District FE & $\mathrm{x}$ & $\mathrm{x}$ \\
Year FE & $\mathrm{x}$ & $\mathrm{x}$ \\
Covariates & $\mathrm{x}$ & $\mathrm{x}$ \\
District-specific linear trends & $\mathrm{x}$ & $\mathrm{x}$ \\
\hline
\end{tabular}

NOTES: YOB stands for the year of birth. Women with more than 5 years of education are the excluded group. The sample is restricted to women above age 20 at the time of survey. The main effects of education groups are included in all regressions but not reported. All regressions include indicators for mother's age at birth, number of previous births, and household's caste and religion dummies. Robust standard errors are in brackets and have been clustered at the district level. All regressions use district-level sampling weights. ${ }^{* * *} 1 \%,{ }^{*} 5 \%, * 10 \%$. 
Table 10: IV Estimates: By Household Wealth Index

\begin{tabular}{|c|c|c|c|}
\hline A. Birth $=1$ & (1) & $(2)$ & (3) \\
\hline Tariff in YOB ${ }^{*}$ Low SLI & $\begin{array}{c}-0.835 * * * \\
{[0.097]}\end{array}$ & $\begin{array}{c}-0.768^{* * *} \\
{[0.090]}\end{array}$ & $\begin{array}{c}-0.710^{* * *} \\
{[0.085]}\end{array}$ \\
\hline Tariff in YOB ${ }^{*}$ High SLI & $\begin{array}{c}0.066 \\
{[0.051]}\end{array}$ & $\begin{array}{c}0.014 \\
{[0.046]}\end{array}$ & $\begin{array}{c}0.005 \\
{[0.046]}\end{array}$ \\
\hline Tariff in YOB & $\begin{array}{c}0.366^{* * *} \\
{[0.054]}\end{array}$ & $\begin{array}{c}0.301^{* * *} \\
{[0.052]}\end{array}$ & $\begin{array}{c}0.235^{* * *} \\
{[0.054]}\end{array}$ \\
\hline $\mathrm{N}$ & $1,857,834$ & $1,857,834$ & $1,857,834$ \\
\hline \multicolumn{4}{|l|}{ B. $B o y=1$} \\
\hline Tariff in YOC $*$ Low SLI & $\begin{array}{l}0.239^{* * *} \\
{[0.110]}\end{array}$ & $\begin{array}{l}0.234^{* *} \\
{[0.111]}\end{array}$ & $\begin{array}{l}0.226^{* *} \\
{[0.112]}\end{array}$ \\
\hline Tariff in YOC ${ }^{*}$ High SLI & $\begin{array}{l}-0.247 \\
{[0.150]}\end{array}$ & $\begin{array}{l}-0.245 \\
{[0.150]}\end{array}$ & $\begin{array}{l}-0.249^{*} \\
{[0.150]}\end{array}$ \\
\hline Tariff in YOC & $\begin{array}{l}-0.022 \\
{[0.097]}\end{array}$ & $\begin{array}{l}-0.018 \\
{[0.097]}\end{array}$ & $\begin{array}{l}-0.009 \\
{[0.102]}\end{array}$ \\
\hline $\mathrm{N}$ & 449,065 & 449,065 & 449,065 \\
\hline \multicolumn{4}{|l|}{ C. Mortality in 12 months } \\
\hline Tariff in YOB $*$ Low SLI & $\begin{array}{c}0.201^{* * *} \\
{[0.054]}\end{array}$ & $\begin{array}{c}0.217^{* * *} \\
{[0.054]}\end{array}$ & $\begin{array}{c}0.178^{* * *} \\
{[0.052]}\end{array}$ \\
\hline Tariff in YOB $*$ High SLI & $\begin{array}{c}0.078 \\
{[0.063]}\end{array}$ & $\begin{array}{c}0.046 \\
{[0.063]}\end{array}$ & $\begin{array}{c}0.054 \\
{[0.063]}\end{array}$ \\
\hline Tariff in YOB & $\begin{array}{c}-0.197^{* * *} \\
{[0.045]}\end{array}$ & $\begin{array}{c}-0.212^{* * *} \\
{[0.046]}\end{array}$ & $\begin{array}{c}-0.169^{* * *} \\
{[0.046]}\end{array}$ \\
\hline $\mathrm{N}$ & 473,430 & 473,430 & 473,430 \\
\hline District FE & $\mathrm{x}$ & $\mathrm{x}$ & $\mathrm{x}$ \\
\hline Year FE & $\mathrm{x}$ & $\mathrm{x}$ & $\mathrm{x}$ \\
\hline Covariates & & $\mathrm{x}$ & $\mathrm{x}$ \\
\hline District-specific linear trends & & & $\mathrm{x}$ \\
\hline
\end{tabular}

NOTES: YOB stands for the year of birth. YOC stands for the year of conception. Medium SLI households are the excluded group. The main effects of High SLI and Low SLI are included in all regressions but not reported. Columns (2)-(3) include indicators for mother's age at birth and number of previous births. Column (2) also includes mother's years of schooling and household's religion and caste dummies. Robust standard errors are in brackets and have been clustered at the district level. All regressions use district-level sampling weights. $* * * 1 \%, * * 5 \%, * 10 \%$. 
Table 11: IV Estimates for Infant Mortality: By Household Wealth Index and Child's Sex

\begin{tabular}{lcc}
\hline Mortality in 12 months & Girls & Boys \\
\hline Tariff in YOB * Low SLI & $0.178^{* * *}$ & $0.174^{* *}$ \\
& {$[0.068]$} & {$[0.071]$} \\
Tariff in YOB * High SLI & -0.090 & 0.023 \\
& {$[0.084]$} & {$[0.082]$} \\
Tariff in YOB & $-0.160^{* *}$ & $-0.173^{* * *}$ \\
& {$[0.063]$} & {$[0.062]$} \\
N & 227,881 & 245,549 \\
\hline District FE & $\mathrm{x}$ & $\mathrm{x}$ \\
Year FE & $\mathrm{x}$ & $\mathrm{x}$ \\
Covariates & $\mathrm{x}$ & $\mathrm{x}$ \\
District-specific linear trends & $\mathrm{x}$ & $\mathrm{x}$ \\
\hline
\end{tabular}

NOTES: YOB stands for the year of birth. Medium-SLI households are the excluded group. The main effects of High-SLI and Low-SLI are included in all regressions but not reported. All regressions include indicators for mother's age at birth, number of previous births, years of schooling, and household's caste and religion dummies. Robust standard errors are in brackets and have been clustered at the district level. All regressions use district-level sampling weights. ${ }^{* * *} 1 \%,{ }^{* *} 5 \%,{ }^{*} 10 \%$. 


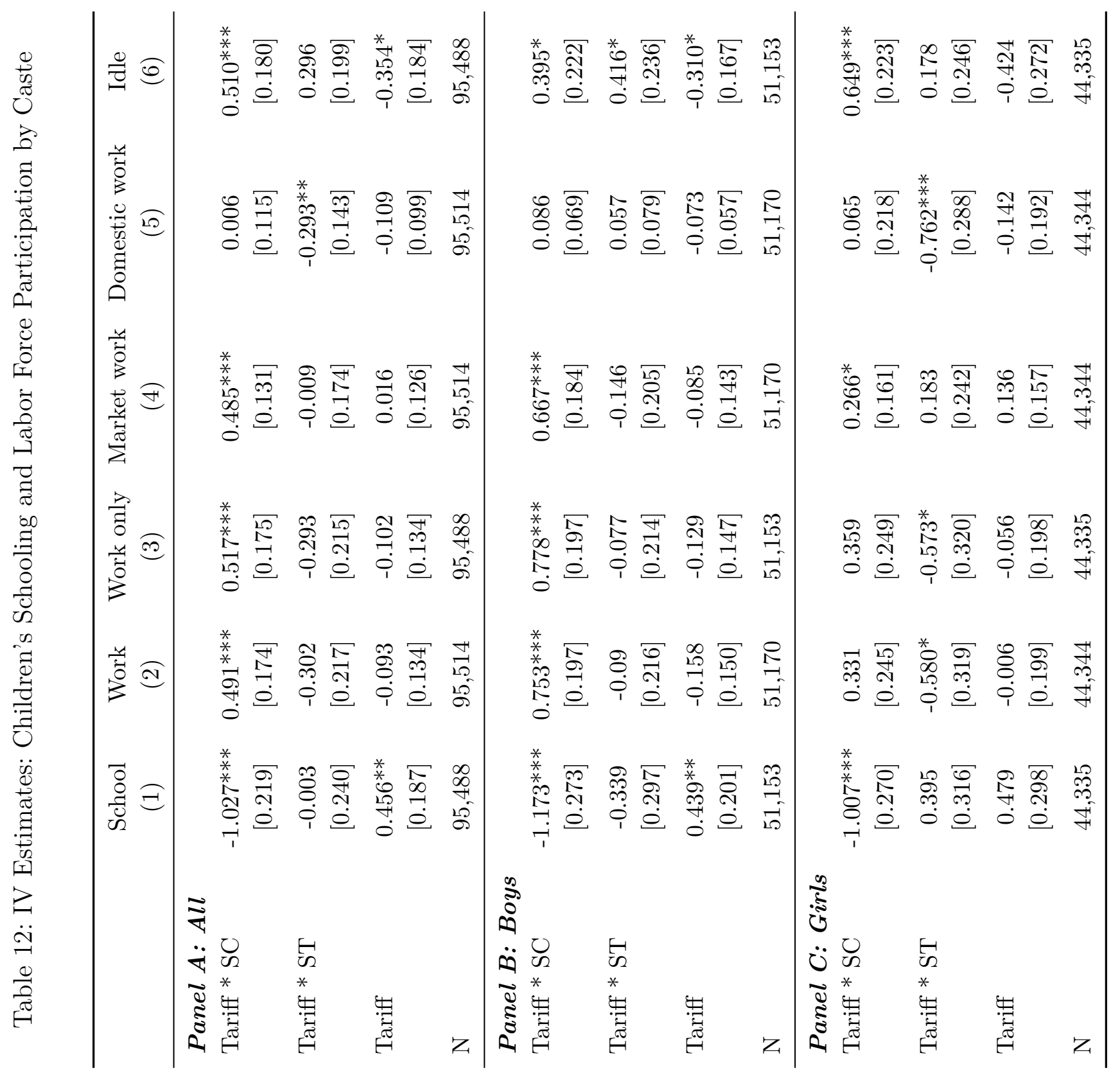

ष्

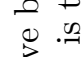
产. సี. 娄 苟 ㅋ. $05 *$ ธี

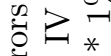
过

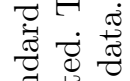
密 苟高 응 की

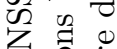
岁需零

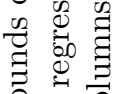

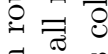
站. ऽ. ఫ्ठ 믈 क्ञ 句 चٓ अध一

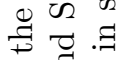
สี ठี च

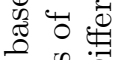
(1) ๘ี

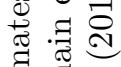
. 0 E छ $\ddot{\sim}$ 巳 
Table 13: IV Estimates: Adult Employment by Caste

\begin{tabular}{lcc}
\hline & Men & Women \\
Days worked in the last year & $(1)$ & $(2)$ \\
\hline Tariff * SC & $329.303^{* * *}$ & $-736.672^{* * *}$ \\
& {$[57.392]$} & {$[87.187]$} \\
Tariff * ST & $201.177^{* *}$ & $-1257.041^{* * *}$ \\
& {$[81.187]$} & {$[210.937]$} \\
Tariff & $-334.291^{* * *}$ & 246.735 \\
& {$[86.667]$} & {$[187.515]$} \\
$\mathrm{N}$ & 99,781 & 112,568 \\
\hline
\end{tabular}

NOTES: These estimates are based on the 43rd and the 55th rounds of NSS. Robust standard errors are in brackets and have been clustered at the district level. The main effects of SC and ST are included in all regressions but not reported. Sample is restricted to adult men and women in the 25-50 age-group. Other controls in this regression are the same as in Table 4 of Edmonds et al. (2010). ${ }^{* * *} 1 \%, * * 5 \%,{ }^{*} 10 \%$.

Table 14: IV Estimates: Migration from Other Districts by Caste and Gender

\begin{tabular}{lc}
\hline Dependent variable - Share in the district population of: & Coefficient of Tariff \\
\hline 1. Female in-migrants & 0.091 \\
& {$[0.082]$} \\
2. Low-caste female in-migrants & 0.043 \\
& {$[0.030]$} \\
3. Female in-migrants who have moved within the last ten years & 0.041 \\
& {$[0.035]$} \\
4. Low-caste female in-migrants who have moved within the last ten years & 0.017 \\
$\mathrm{~N}$ & {$[0.015]$} \\
\hline
\end{tabular}

NOTES: These estimates are based on the 43rd and the 55th rounds of NSS. Each coefficient is from a different regression. Robust standard errors are in brackets and have been clustered at the district level. Low-caste refers to SC and ST women. In-migrants refers to individuals whose place of enumeration is in a district different from their last place of usual residence. Regressions are weighted by the number of households in a district and control for district and year fixed effects and initial district conditions that are interacted with the post-reform indicator. ${ }^{* * *} 1 \%,{ }^{*} 5 \%,{ }^{*} 10 \%$. 


\section{A Appendix Tables}

Table A.1: IV Estimates: Urban India

\begin{tabular}{|c|c|c|c|c|c|}
\hline Birth $=1$ & (1) & $(2)$ & $(3)$ & $(4)$ & $(5)$ \\
\hline \multicolumn{6}{|l|}{ A1. First Stage } \\
\hline Traded Tariff in YOB & $\begin{array}{c}0.317^{* * *} \\
{[0.030]}\end{array}$ & $\begin{array}{c}0.317^{* * *} \\
{[0.030]}\end{array}$ & $\begin{array}{c}0.325^{* * *} \\
{[0.029]}\end{array}$ & $\begin{array}{c}0.315^{* * *} \\
{[0.029]}\end{array}$ & $\begin{array}{c}0.323^{* * *} \\
{[0.028]}\end{array}$ \\
\hline F-stat & 108.05 & 108.3 & 126.43 & 118.72 & 135.13 \\
\hline \multicolumn{6}{|l|}{ B1. IV } \\
\hline Tariff in YOB & $\begin{array}{c}-0.100^{* *} \\
{[0.049]}\end{array}$ & $\begin{array}{c}-0.141^{* * *} \\
{[0.047]}\end{array}$ & $\begin{array}{c}-0.143^{* * *} \\
{[0.045]}\end{array}$ & $\begin{array}{c}-0.230^{*} \\
{[0.127]}\end{array}$ & $\begin{array}{c}-0.307^{* * *} \\
{[0.115]}\end{array}$ \\
\hline $\mathrm{N}$ & 895,134 & 895,134 & 895,134 & 895,134 & 895,134 \\
\hline \multicolumn{6}{|l|}{ Boy $=1$} \\
\hline \multicolumn{6}{|l|}{ A2. First Stage } \\
\hline Traded Tariff in YOC & $\begin{array}{c}0.292^{* * *} \\
{[0.028]}\end{array}$ & $\begin{array}{c}0.292^{* * *} \\
{[0.028]}\end{array}$ & $\begin{array}{c}0.302^{* * *} \\
{[0.027]}\end{array}$ & $\begin{array}{c}0.279^{* * *} \\
{[0.022]}\end{array}$ & $\begin{array}{c}0.288^{* * *} \\
{[0.024]}\end{array}$ \\
\hline $\begin{array}{l}F \text {-stat } \\
\text { B2. IV }\end{array}$ & 111.27 & 111.56 & 122.24 & 158.02 & 149.55 \\
\hline Tariff in YOC & $\begin{array}{c}-0.040 \\
{[0.110]}\end{array}$ & $\begin{array}{c}-0.033 \\
{[0.110]}\end{array}$ & $\begin{array}{c}0.050 \\
{[0.109]}\end{array}$ & $\begin{array}{l}-0.251 \\
{[0.155]}\end{array}$ & $\begin{array}{l}-0.238 \\
{[0.151]}\end{array}$ \\
\hline $\mathrm{N}$ & 186,953 & 186,953 & 186,953 & 186,953 & 186,953 \\
\hline \multicolumn{6}{|l|}{ C1. Mortality in 1 month } \\
\hline Tariff in YOB & $\begin{array}{l}-0.012 \\
{[0.034]}\end{array}$ & $\begin{array}{l}-0.009 \\
{[0.034]}\end{array}$ & $\begin{array}{c}0.012 \\
{[0.033]}\end{array}$ & $\begin{array}{l}-0.013 \\
{[0.052]}\end{array}$ & $\begin{array}{c}0.017 \\
{[0.051]}\end{array}$ \\
\hline \multicolumn{6}{|l|}{ C2. Mortality in 6 months } \\
\hline Tariff in YOB & $\begin{array}{l}-0.030 \\
{[0.035]}\end{array}$ & $\begin{array}{l}-0.027 \\
{[0.035]}\end{array}$ & $\begin{array}{l}-0.009 \\
{[0.035]}\end{array}$ & $\begin{array}{l}-0.025 \\
{[0.055]}\end{array}$ & $\begin{array}{l}-0.001 \\
{[0.055]}\end{array}$ \\
\hline \multicolumn{6}{|l|}{ C3. Mortality in 12 months } \\
\hline Tariff in YOB & $\begin{array}{l}-0.033 \\
{[0.038]}\end{array}$ & $\begin{array}{l}-0.030 \\
{[0.039]}\end{array}$ & $\begin{array}{l}-0.002 \\
{[0.038]}\end{array}$ & $\begin{array}{l}-0.038 \\
{[0.059]}\end{array}$ & $\begin{array}{l}-0.001 \\
{[0.057]}\end{array}$ \\
\hline \multicolumn{6}{|l|}{ C4. First Stage } \\
\hline Traded Tariff in YOB & $\begin{array}{c}0.300^{* * *} \\
{[0.029]}\end{array}$ & $\begin{array}{c}0.300^{* * *} \\
{[0.029]}\end{array}$ & $\begin{array}{c}0.308^{* * *} \\
{[0.028]}\end{array}$ & $\begin{array}{c}0.283^{* * *} \\
{[0.023]}\end{array}$ & $\begin{array}{c}0.290^{* * *} \\
{[0.023]}\end{array}$ \\
\hline F-stat & 105.37 & 105.63 & 121.76 & 149.57 & 152.44 \\
\hline $\mathrm{N}$ & 198,400 & 198,400 & 198,400 & 198,400 & 198,400 \\
\hline District FE & $\mathrm{x}$ & $\mathrm{x}$ & $\mathrm{x}$ & & \\
\hline Year FE & $\mathrm{x}$ & $\mathrm{x}$ & $\mathrm{x}$ & $\mathrm{x}$ & $\mathrm{x}$ \\
\hline Covariates & & $\mathrm{x}$ & $\mathrm{x}$ & $\mathrm{x}$ & $\mathrm{x}$ \\
\hline District-specific linear trends & & & $\mathrm{x}$ & & $\mathrm{x}$ \\
\hline Mother FE & & & & $\mathrm{x}$ & $\mathrm{x}$ \\
\hline
\end{tabular}

NOTES: YOB stands for the year of birth. YOC stands for the year of conception. Each cell constitutes a separate regression. Columns (2) - (5) include indicators for mother's age at birth and number of previous births. Columns (2) and (3) also include mother's years of schooling and household's religion and caste dummies. Robust standard errors are in brackets and have been clustered at the district level. All regressions use district-level sampling weights. ${ }^{* * *} 1 \%, * * 5 \%,{ }^{*} 10 \%$. 